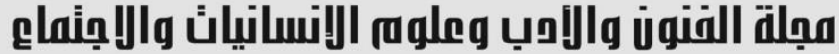

Journal of Arts, Literature, Humanities and Social Sciences www.jalhss.com

\section{نمط الأسرة الصحي وعلاقته بالسمنة عند الأبناء والمراهقين}

\author{
أستاذ مساعد/ انجي عبد الحميد جمال حريزي

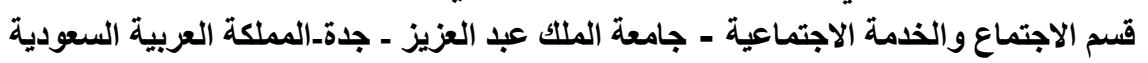 \\ البريد الاكتروني: enjeehariri@hotmail.com
}

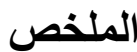

هدفت هذه الدراسة إلى التعرف على اختلاف السمنة عند الأبناء والمر اهقين باختلاف متغير النوع (الآباء-

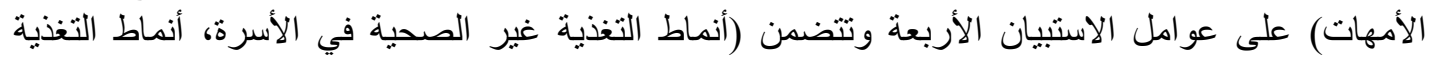

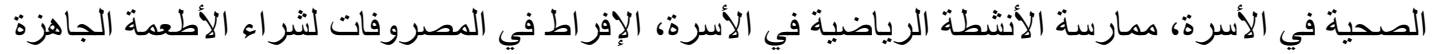

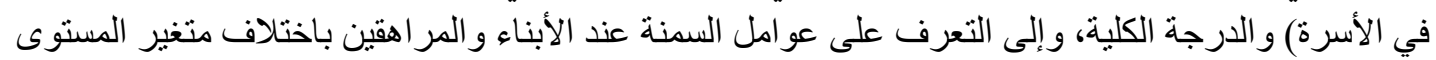

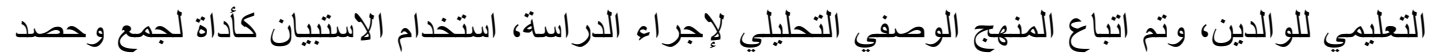

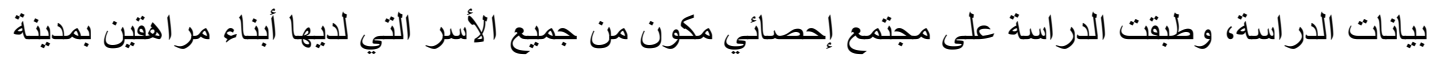

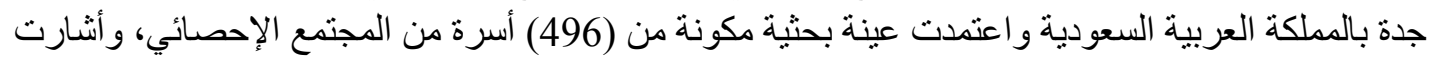

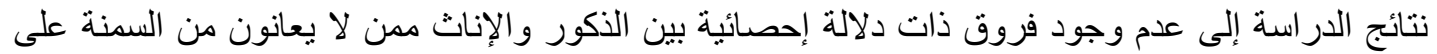

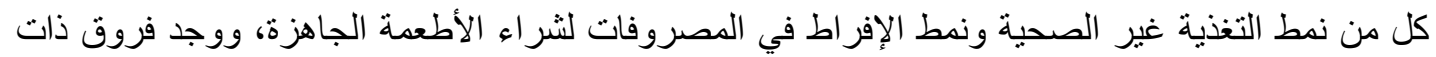

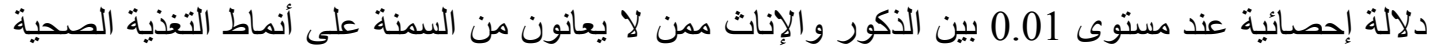

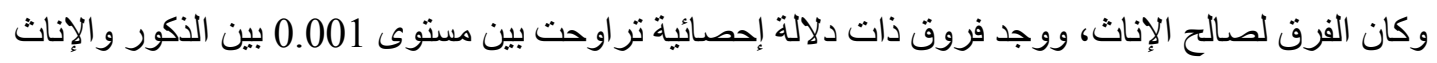

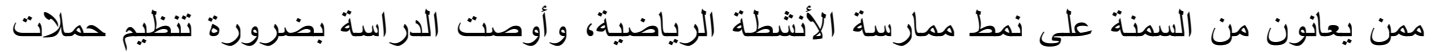

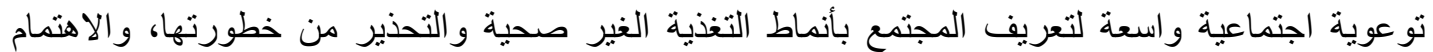

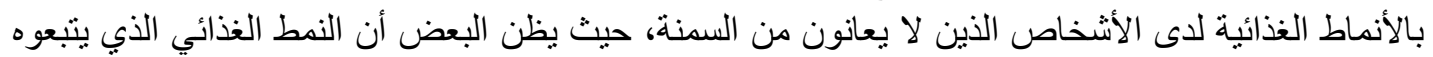




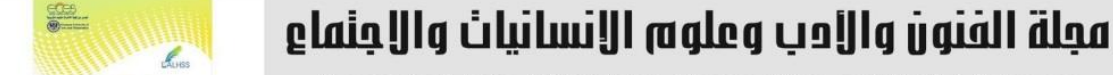 \\ Journal of Arts, Literature, Humanities and Social Sciences wWw.jalhss.com \\ Volume (68) June 2021 \\ 2021 ( ) \\ العدد (68) (2) (2) (2)

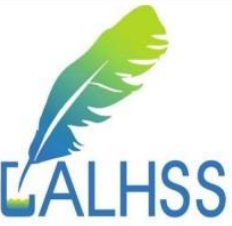 \\ A Family's Health Pattern and its Relationship to Obesity in Children and Adolescents
}

\author{
Enjee Abd alhamid Jamal Hariri \\ Department of Sociology and Social Work - King Abdulaziz University - Jeddah-Saudi \\ Arabia \\ Email: enjeehariri@hotmail.com
}

\begin{abstract}
This study aimed to identify the differences in obesity among children and adolescents according to the differences of the variable of gender (fathers-mothers) on the questionnaire's (4) items, which include (family's unhealthy diet patterns, family's healthy diet patterns, practicing sports activities in the family, excessive expenses to buy ready foods in the family). The study also aimed to identify the factors of obesity in children and adolescents according to the variable of the parents' educational level. The study followed the descriptive analytical approach to conduct the study; where the questionnaire was used as a tool to collect the study data. The study was applied to a statistical community that included all families with teenage children in Jeddah, Saudi Arabia; selecting a sample of (496) families. The results of the study indicated that no statistically significant differences were found between males and females who do not suffer from obesity on both the unhealthy diet pattern and the pattern of excessive expenses to buy ready foods. Moreover, the study found statistically significant differences at the level of 0.01 between males and females who do not suffer from obesity on healthy diet patterns; where the difference was in favor of females. The study also found statistically significant differences between the level of 0.001 between males and females who suffer from obesity on the pattern of practicing sports activities. The recommended the necessity of organizing social awareness campaigns to inform the community about unhealthy eating patterns and warn of their dangers and pay attention to the diet patterns of people who do not suffer from obesity; as some would believe that the diet, they follow is healthy and adequate.
\end{abstract}

Keywords: family, pattern, obesity, children, teenagers, healthy. 


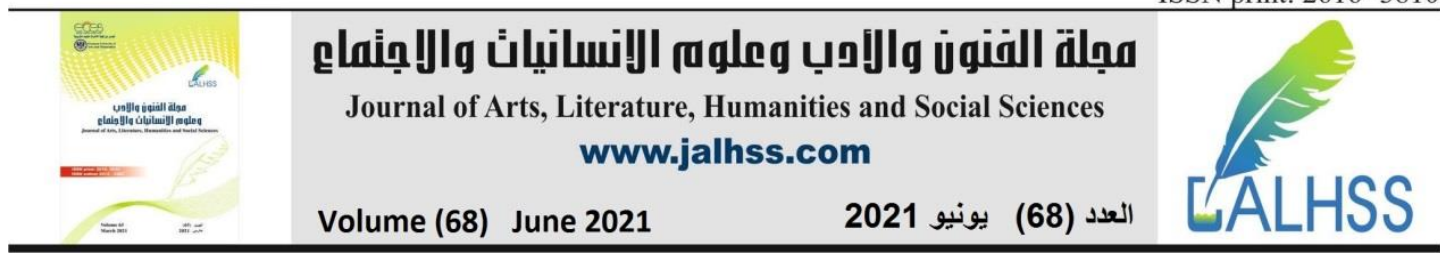

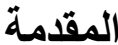

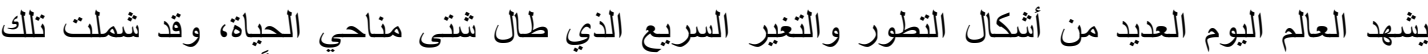

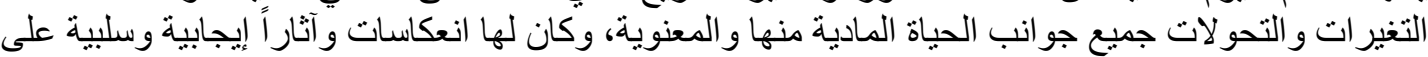

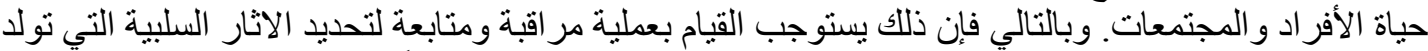

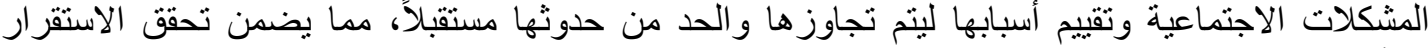

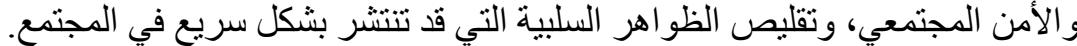

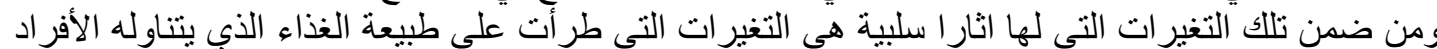

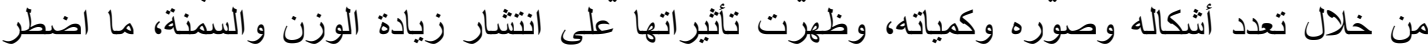

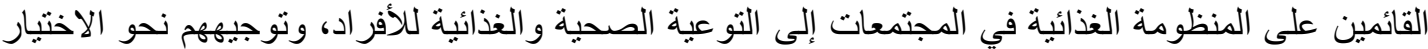

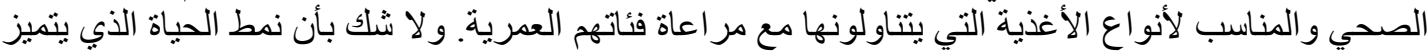

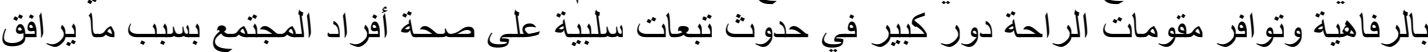

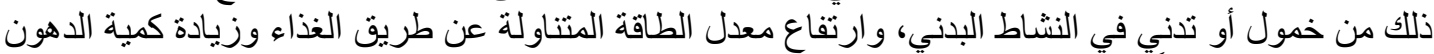

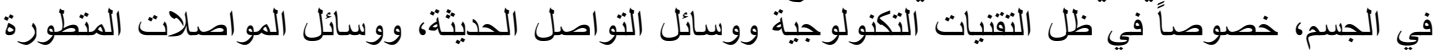

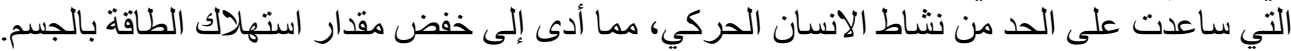

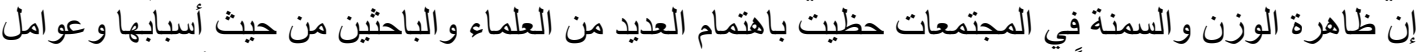

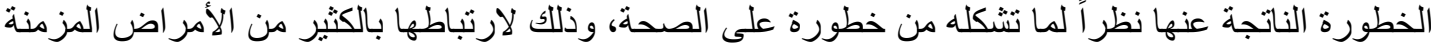

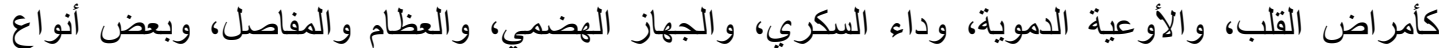

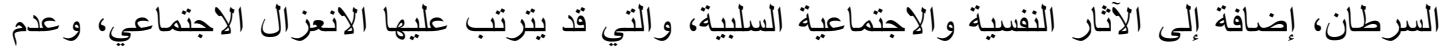

الاشتر اك في كثير من المناثط الاجتماعية (Sahoo et al, 2015, Wang, 2017).

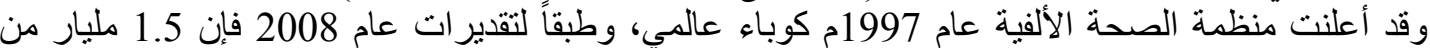

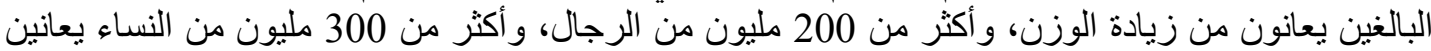

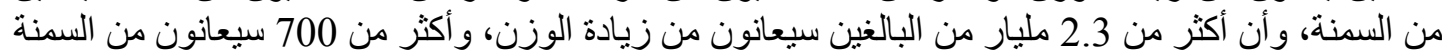

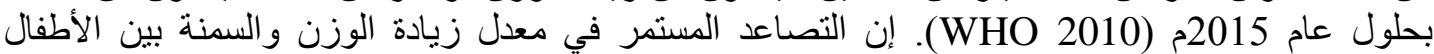

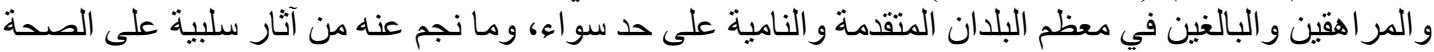

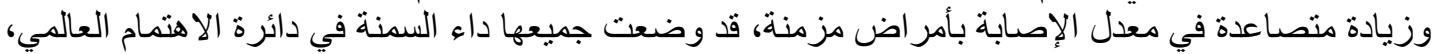

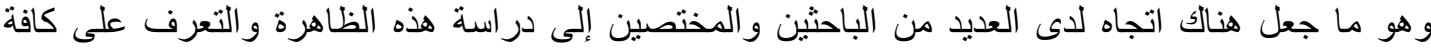

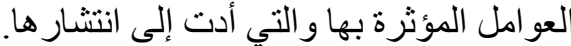

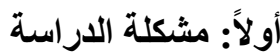

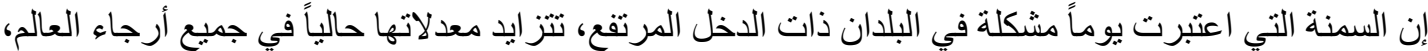

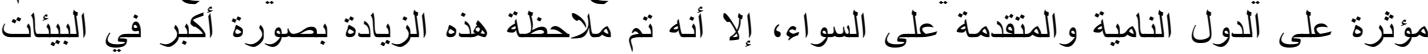

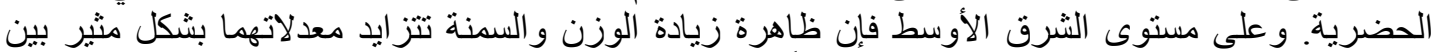

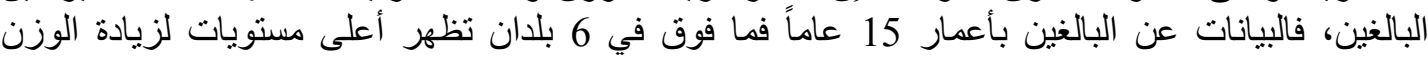

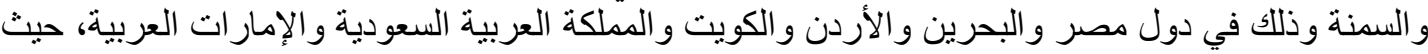

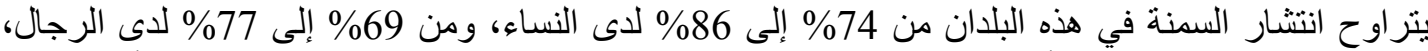

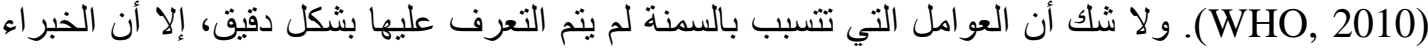

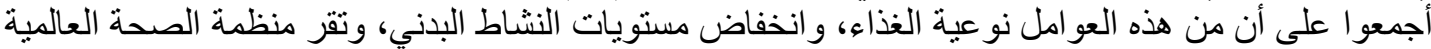

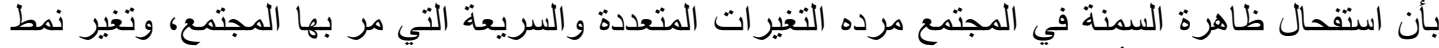

المعيشة ونمط صناعة الأغذية ونوزيعها وتسويقها (WHO, 2016, Williams and Greene, 2018).

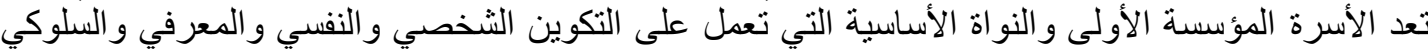

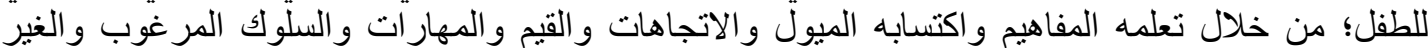

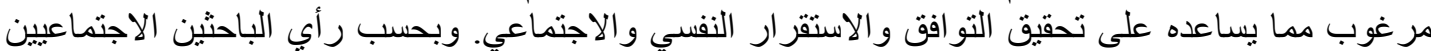

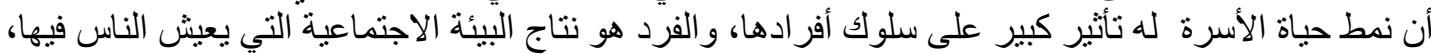

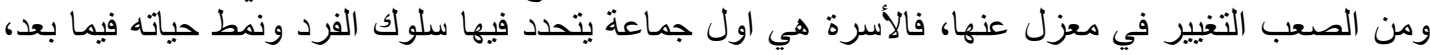




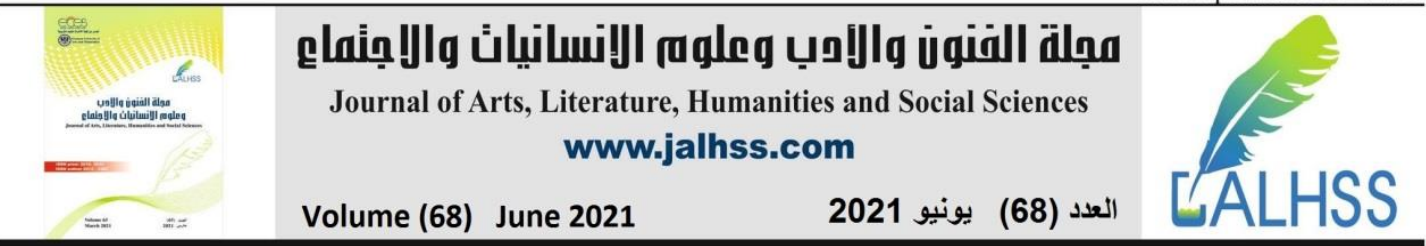

ومن خلال الأسرة يتشكل اهتمام الأبناء بممارسة الانشطة البدنية ويظهر ميلهم إلى تناول أغذية محددة دون

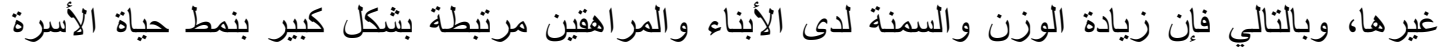

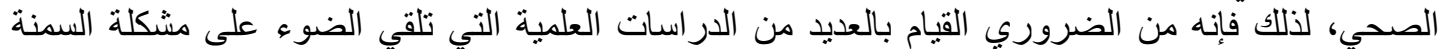
وتساهم في معرفة الأسباب و العو امل المرتبطة بها لون (Danford et al, 2015, Wang, 2017).

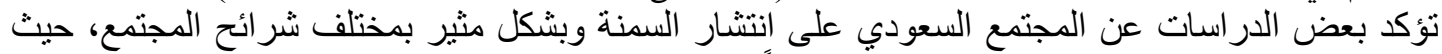

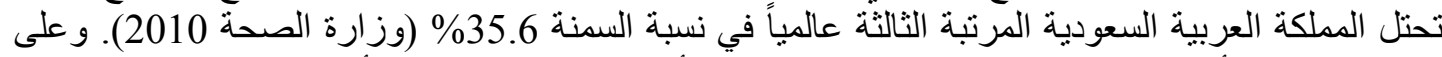

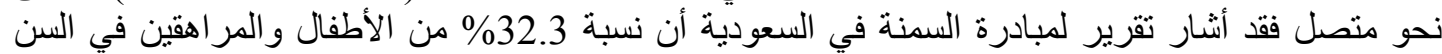

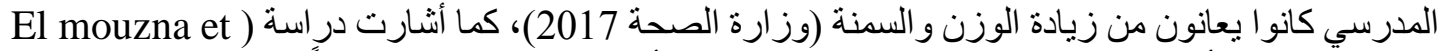

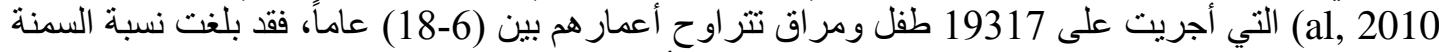

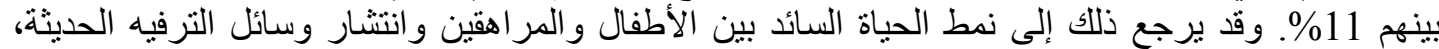

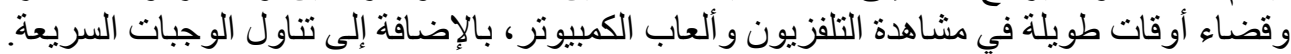

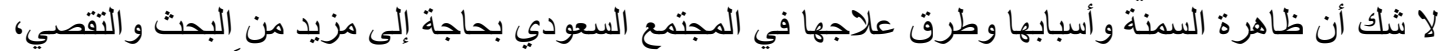

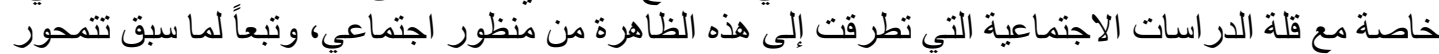
مشكلة هذه الدر اسة في التعرف على الأن الأهداف التالية:

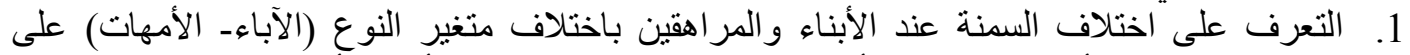

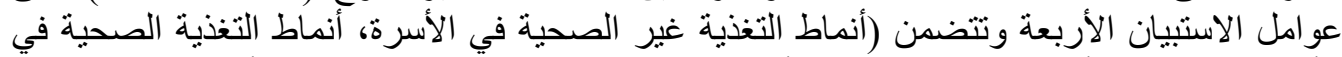

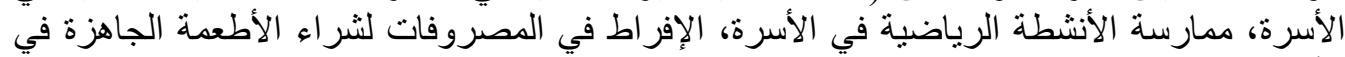
الأسرة) و الدرجة الكلية.

2. التعرف على عو امل السمنة عند الأبناء و المر اهقين باختلاف متغير المستوى التعليمي للو الدين.

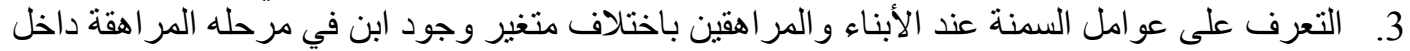
الأسرة من عدمها. 4. التعرف على عو امل السمنة عند الأبناء والمر اهقين باختلاف متغير الدخل الشهري للأسرة. ثانياً: تساؤلات الاراسة

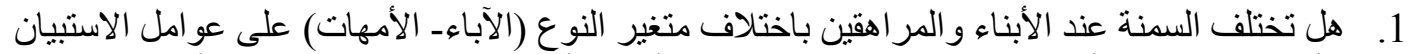

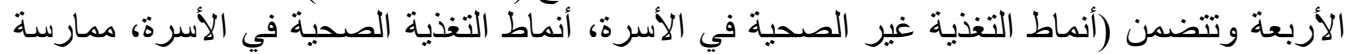

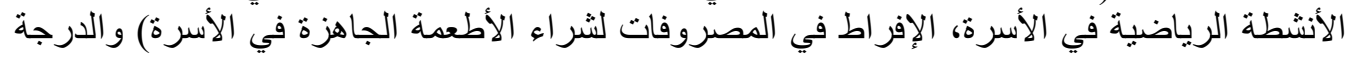
الكلبة؟

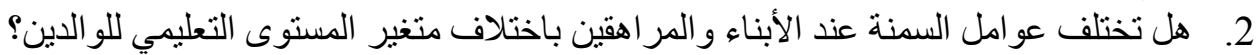

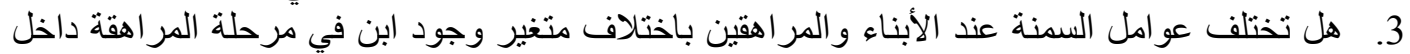
الأسرة من عدمهـ 4. هل تختلف عو امل السمنة عند الأبناء و المر اهقين باختلاف متغير الدخل الشهري للأسرة؟

تالثاً: أهمية الدراسة تتمثل أهية هذه الدراسة في التعرف على التغيرات التي حدثت في طريقة الاستهلاك الغذائي، وكيفية الحياة

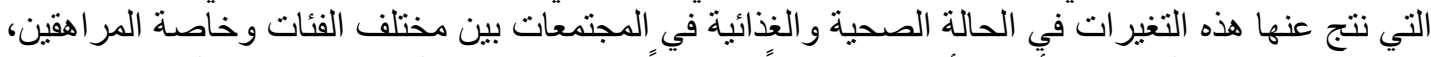
حيث تعتبر ظاهرة السمنة من أكثر الأمر اض شيو عاً وانتشارًاً بين جميع فئات المجتمع وخاصة المر اهقين.

الأهمية النظرية 1. يتوقع من هذه الدراسة أن تثري المكتبة العربية في هذا المجال، خاصة مع قلة الدراسات في هذا المجال، وذللك على حد على علم الباحثة. 2. أهمية الفئة المبحوثة، وهي ولئ الأبناء وخاصة المر الهقين منهم، وذلك لأنهم جيل المستقبل الذي سوف يسعى إلى تنمية وتطوير المجتمع. 


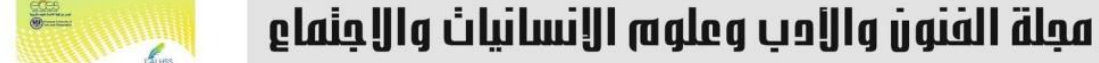 \\ Journal of Arts, Literature, Humanities and Social Sciences www.jalhss.com

3. تأمل هذه الدراسة أن توجه الباحثين نحو المجالات البحثية المتعلقة برفع مستوى الوعي الصحي

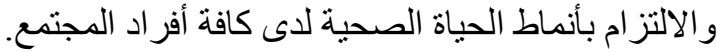

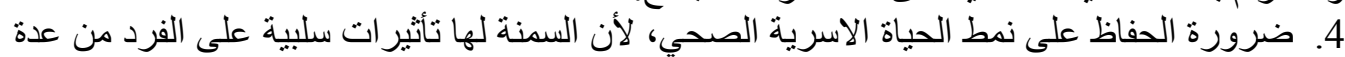
جو انب صحية ونفسية و اجتماعية.

الأهمية التطبيقية

1. أن تساهم في وضع سياسات اجتماعية تسعى إلى توفير بيئة اجتماعية تدعم اتباع نمط حياة صحي بما يضمن تحسن صحة أجيال المستقبل.

2. أن تساهم في الوقوف على واقع نمط الحياة الصحي لدى الأسر السعودية.

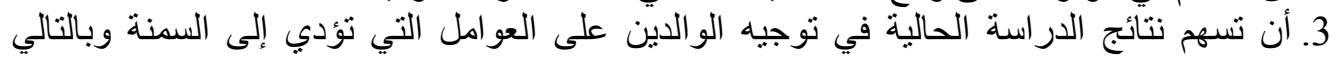

$$
\text { تساعدهم على تبني نمط حياة صحي. }
$$

4. أن تساهم نتائج الدر أسة الحالية في توجيه الو الدين نحو الحد من العادات و الممارسات الغير صحية.

الحدود الموضو عية: تتمثل في التعرف على نمط الأسرة و علاقته بالسمنة عند الأبناء و المر اهقين.

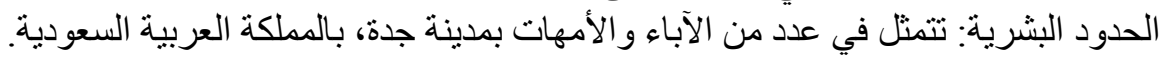

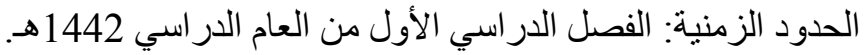
الحدود المكانية: سيتم تطبيق الدراسة بمدينة جدة، المملكة العربية السعودية.

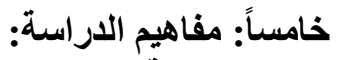

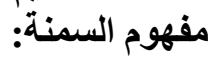
يعرَّف الوزن الز ائد والسمنة بأنهما تر اكم غير طبيعي أو مفرط للاهون قد يلحق الضرر بالصحة. وحساب كتلة

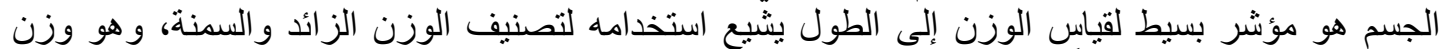

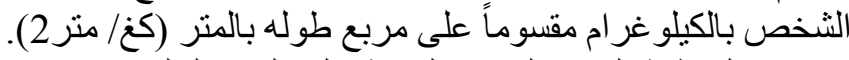

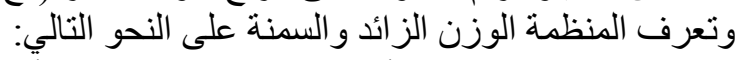

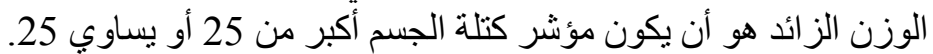

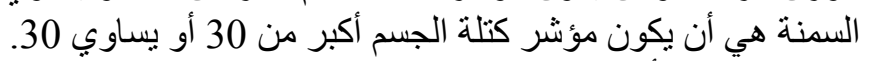

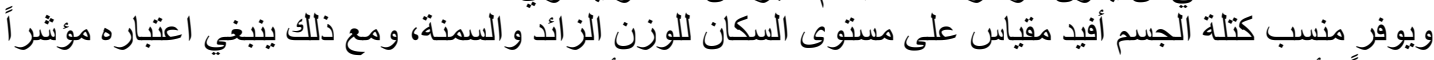

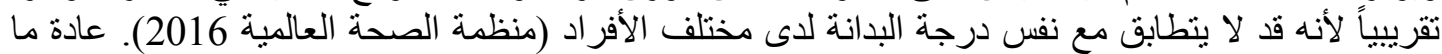

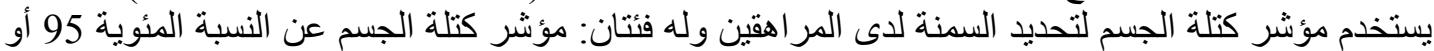
أكثر للعمر والجنس، أو مؤشر كتلة الجسم الذي يزيد عن 30. 30. ويعد مؤشر كتلة الجسم بين النسبة النسية المئوية 85 و95، أو مؤشر كتلة الجسم يساوي 30 أو أكبر (Stanford Medicine, 2020).

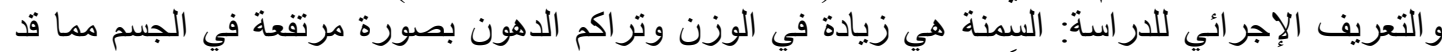

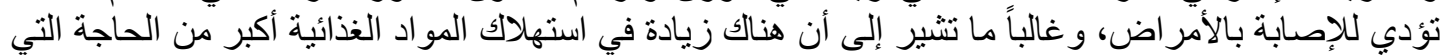

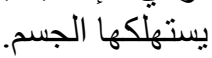

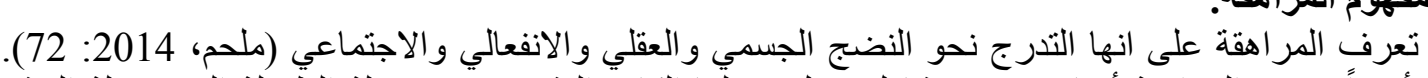

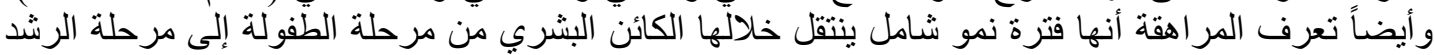

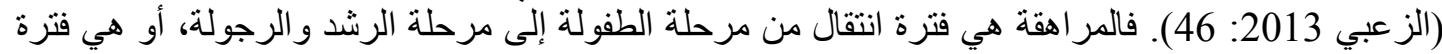

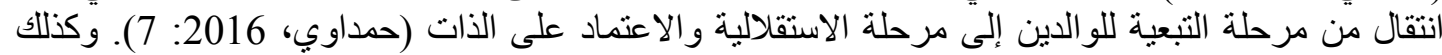

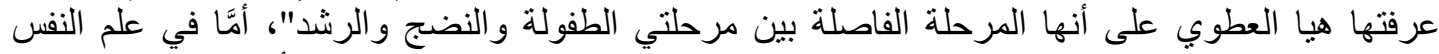
المعاصر، فهي المرحلة التي تلي البلوغ، وهي غالبًا من الثانية عشرة إلى التاسعة عشرة أو الحادية و العشرين. 


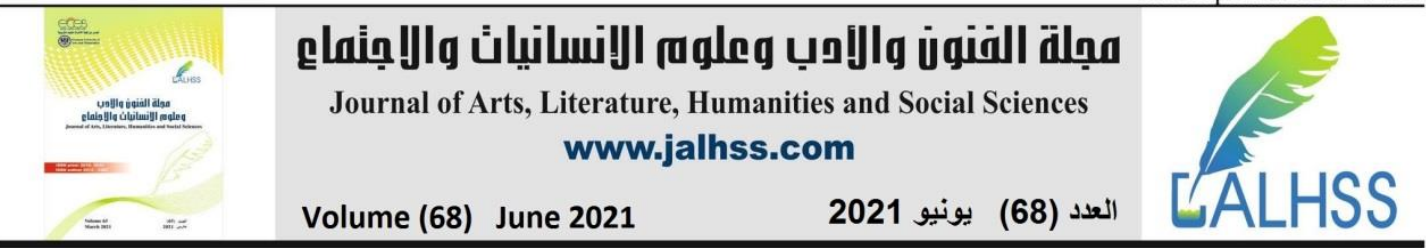

فعلماءُ النفس يُصنفون مَن كان في هذه السنّ مُر اهِقًا تَحكمه خصائص معينة وطبيعة مُعينة (العطوي 1439:

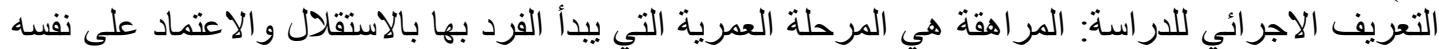

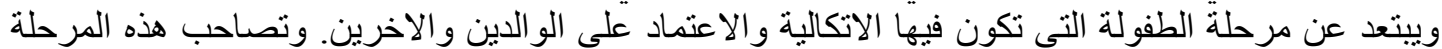
العمرية تغير ات جسمية وإحساس بالذات و إدر الك أكبر للبيئة المحيطة.

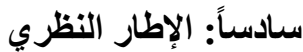 \\ أولاً: النظريات الإطار المستخدمة في الاربة استة}

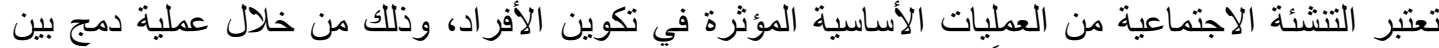

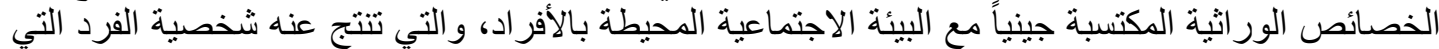

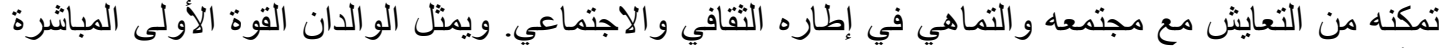

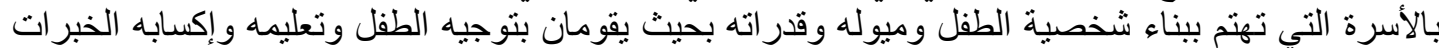

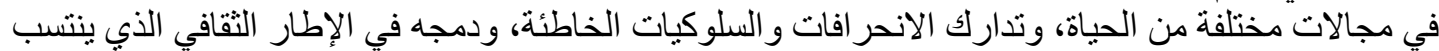

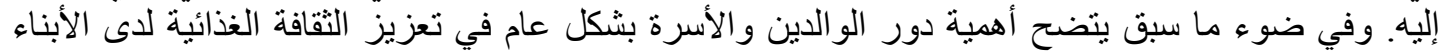

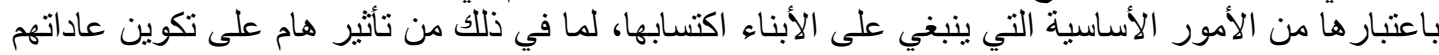

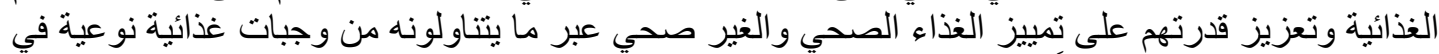

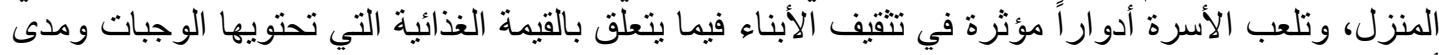

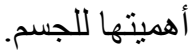

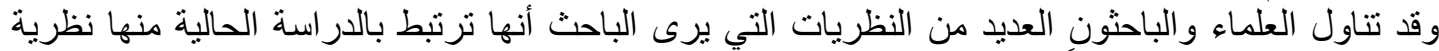

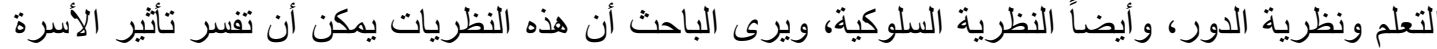

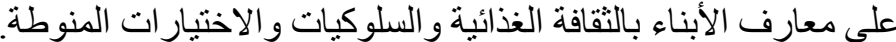

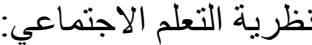

وتعتمد هذه النظرية على الاحئ المحيط الاجتماعي كأساس أو كأصل لنشوء حالة العدورئ العدوان، من خلال الملاحظة

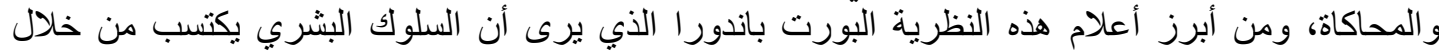

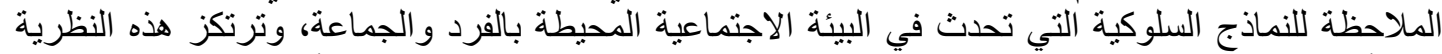

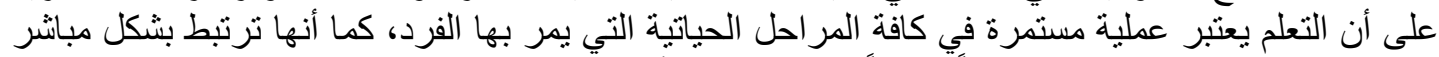

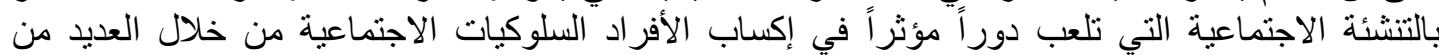

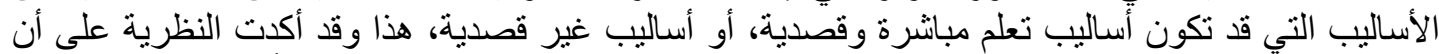

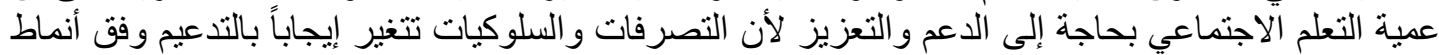

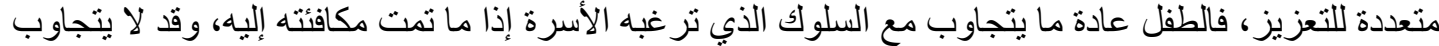

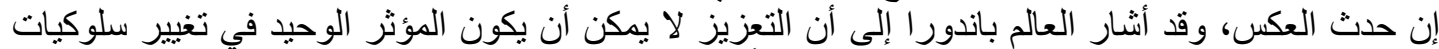

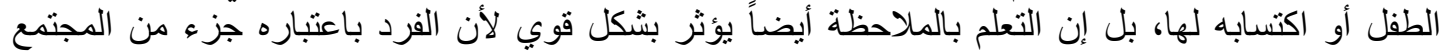

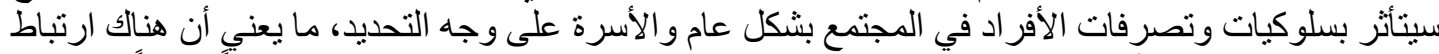

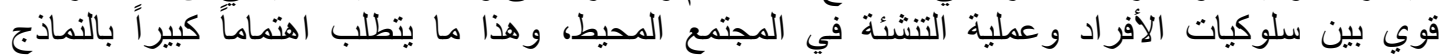

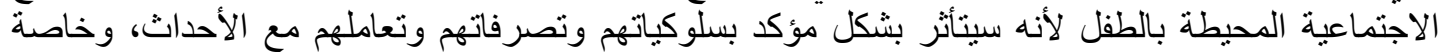

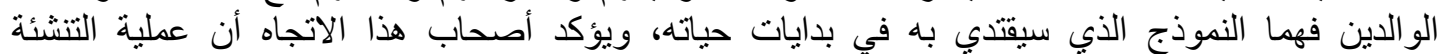

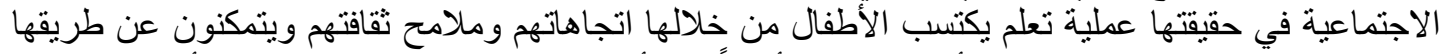

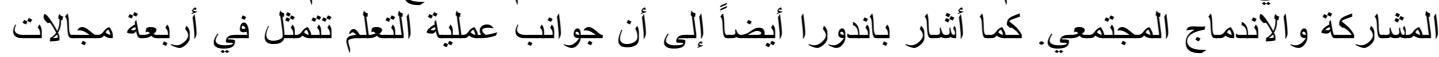

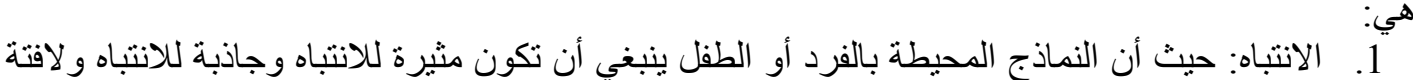




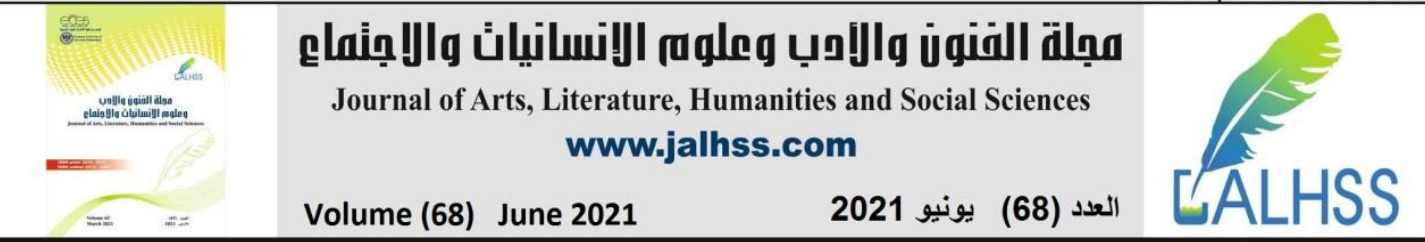

4. الحافز : لا شك بأن الحافز لدى الفرد أو الطفل في غاية الأهمية، نظر اً لأنه محرك أساسي تجاه تحسين

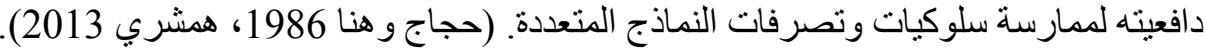

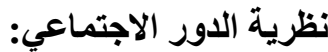

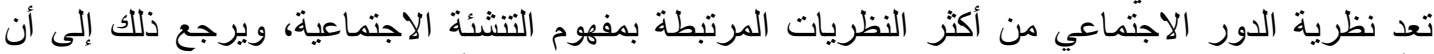

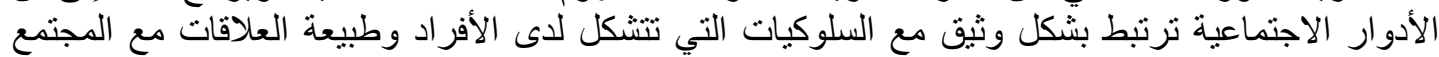

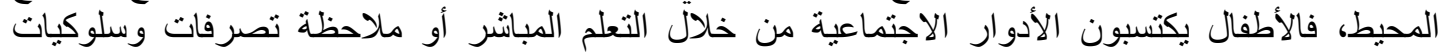

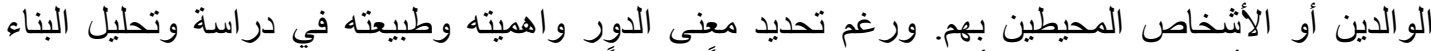

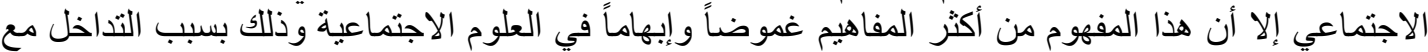

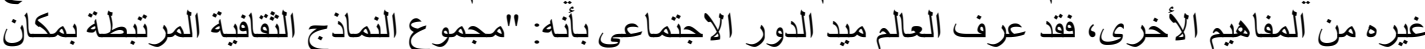

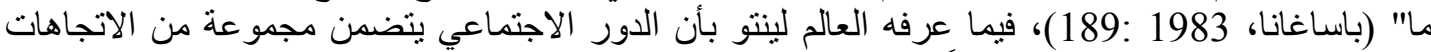

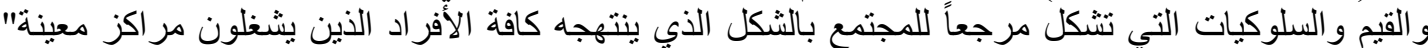

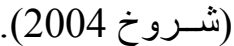

واهتمت نظرية الدور بالتعرف على مضامين السلوكيات الإنسانية والعوامل المؤثرة سواء في الجانب

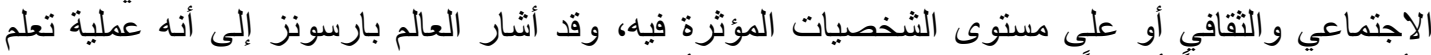

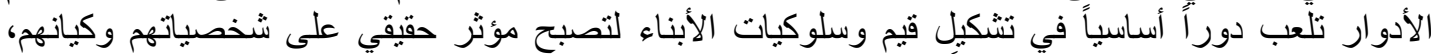

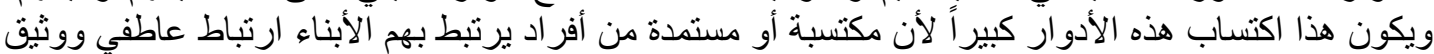

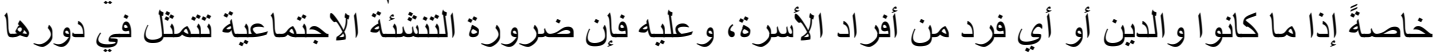

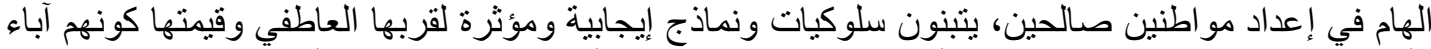

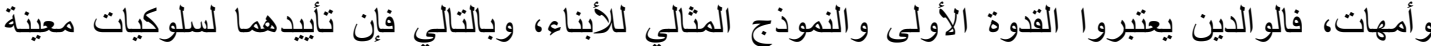

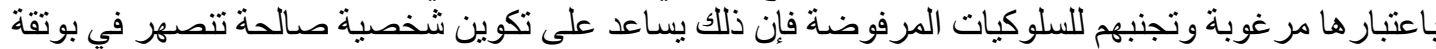

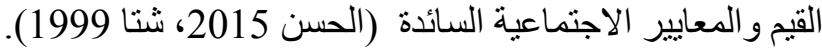

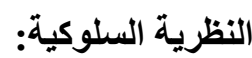

تعتقد هذه النظرية أن السلوك الإنساني ينكون من القيم، المعايير والعادات التي يكتسبها الفرد من البيئة

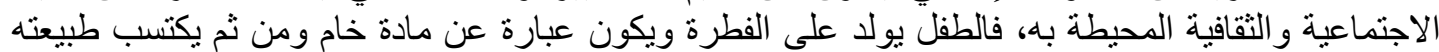

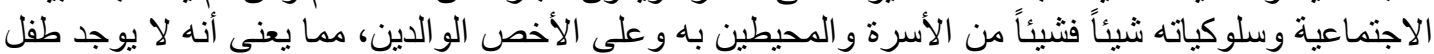

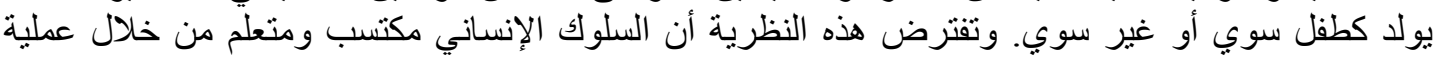

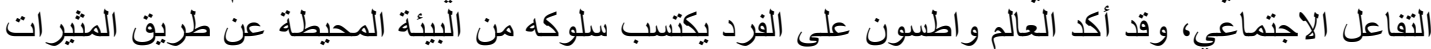

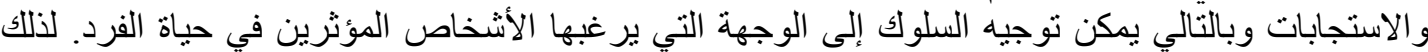

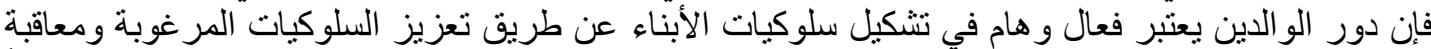

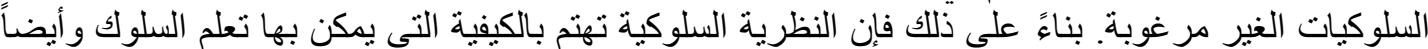

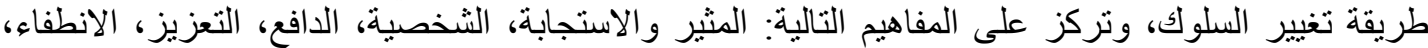

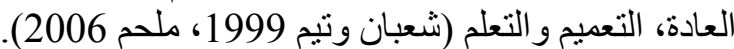

ثُانياً: أسباب السمنة

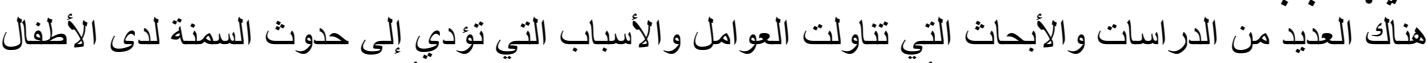

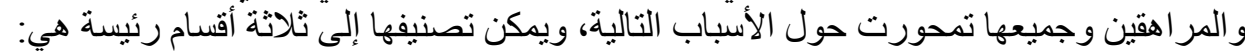

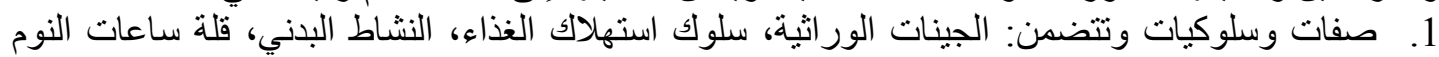

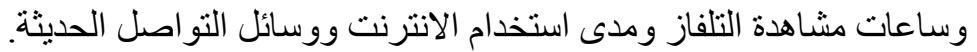
2. نمط الأسرة وخصائص الوالدين: ولها تأثيثر كبير في تشكيل سلوكيات الأبناء نحو نوعية الغذاء وكمية

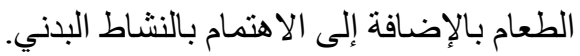
3. خصائص المجتمع: وتؤثر في سلوكيات كل من الوالألئن الاين والأبناء وكل أفراد المجتمع وتتضمن: المستوى

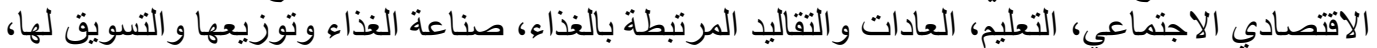




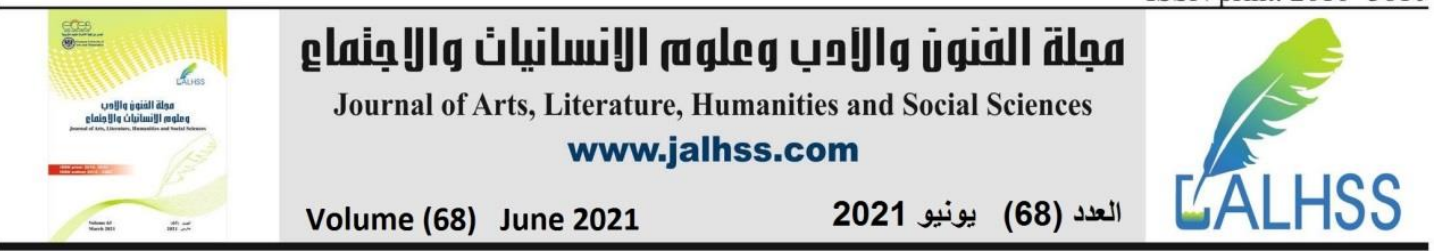

اعتماد على المواصلات الحديثة والبيئة الطبيعية ( Williams and Greene, 2018, Wang,

ثالثاً: الاراسات السابقة

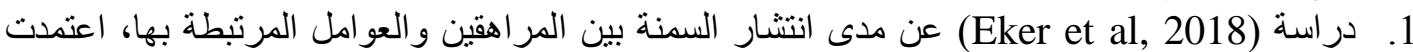

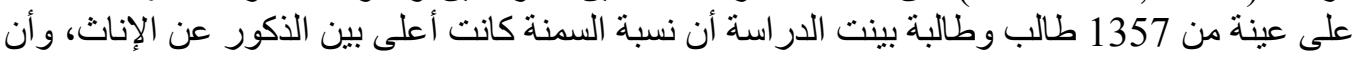

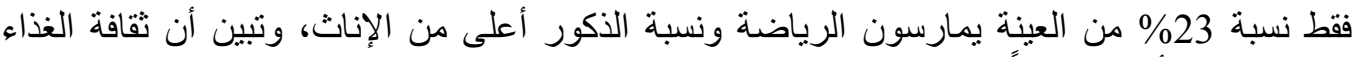

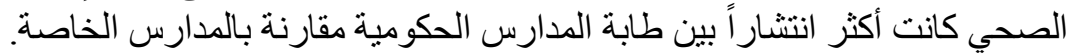

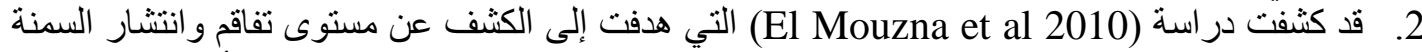

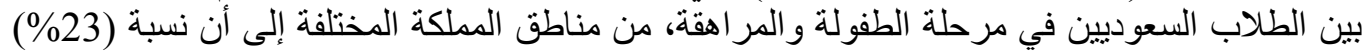

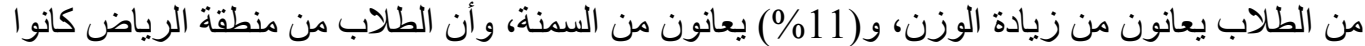

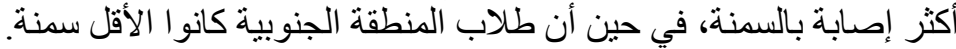

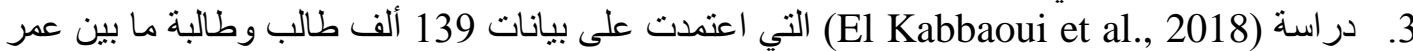

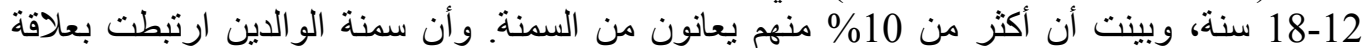

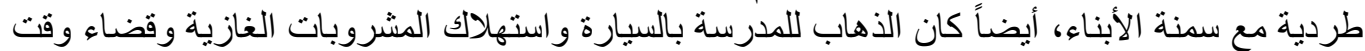

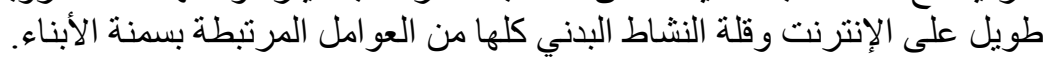

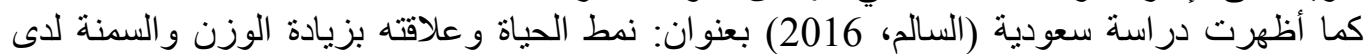

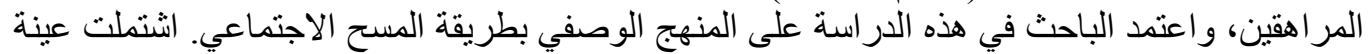

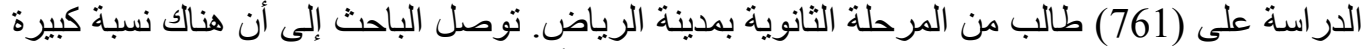

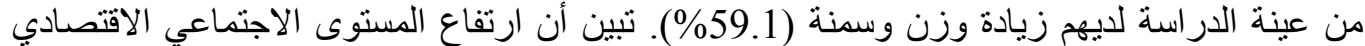

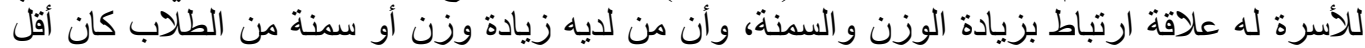

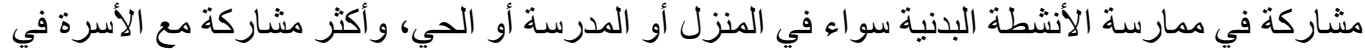
حضور المناسبات الاجتماعية. 5. و أوضحت دراسة (Hazzaa et al., 2014) عن مدى انتشار السمنة بين المر اهقين في ثلاثة مدن رئيسة في السعودية أن نسبة السمنة كانت أكبر لدى الذكور وبلغت 24\% من أفراد العينة وبلغت بين العين الإناث 14\% وبينت الدراسة انتشار نسبة السمنة بين المر اهقين السعوديين مما يعد مؤشر سلبي على صحتهر الئه البدنية.

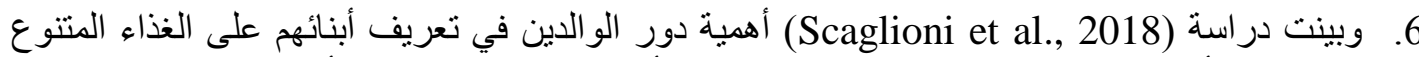

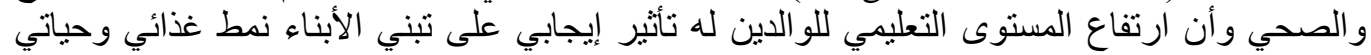

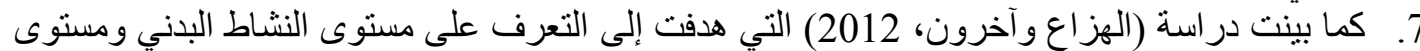

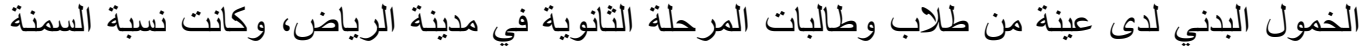

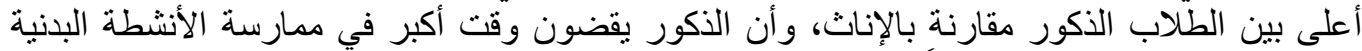

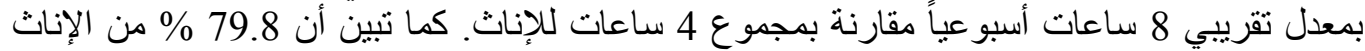

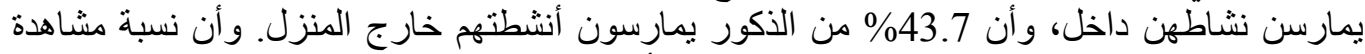

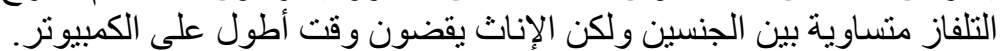

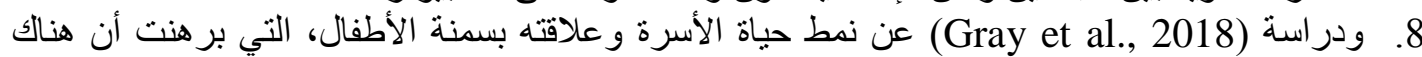

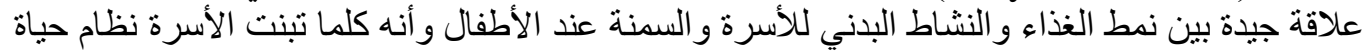
صحي كلما قلت فرص اكتن نسطاب أبنائهم للسمنة.

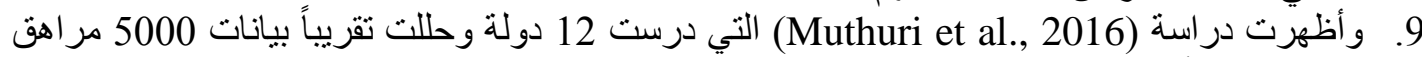

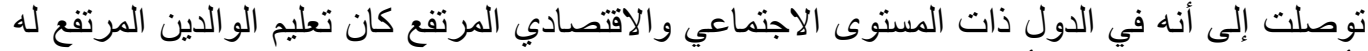
تأثير عكسي على سمنة الأبناء.

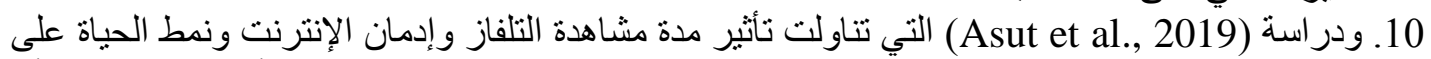

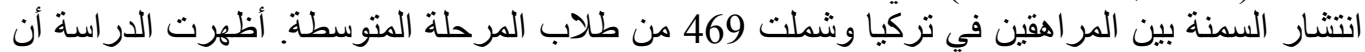




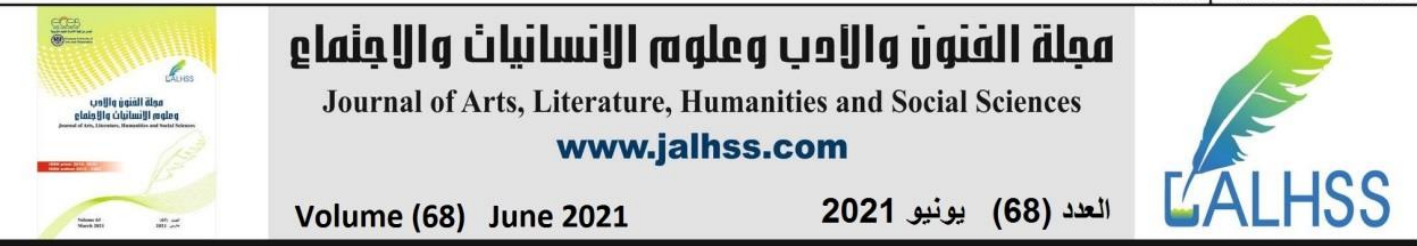

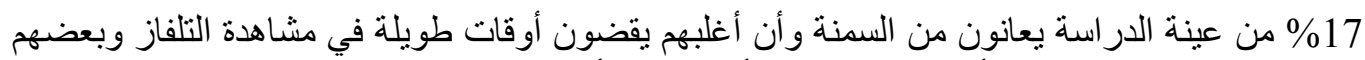

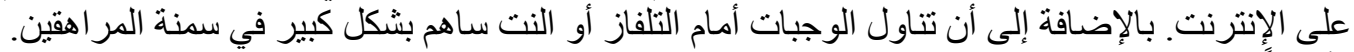

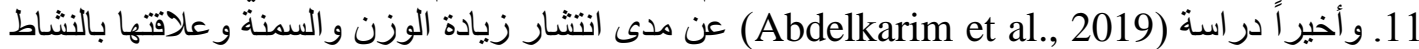

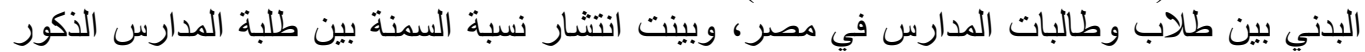
و الإناتث، لكن الذكور كانو ا أفضل من ناحية الاهتمام بالنشاط البدني و الرياضة مقارنة النالة بالإناث.

التعقيب على الاراسات السابقة تمثلت أوجه الاستفادة من الدراسات الكاتة السابقة في اختيار المنهج المناسب و الأداة المناسبة بالإضافة إلى استخدام

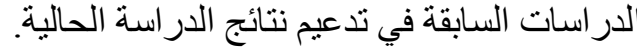
أوجه تميز الدراسة الحالية عن الدراسات الدات السابقة:

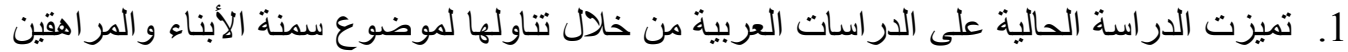
من ناحية تأثير نمط الأسرة الصحي و علاقته بانتشار السمنة في المجتمع، بما أن سلوك الأبناء هو نتاج الهاء

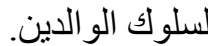

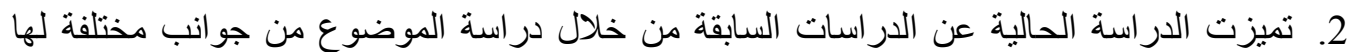

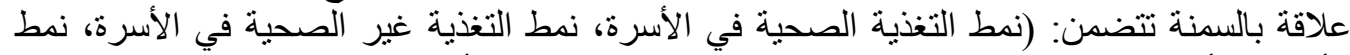

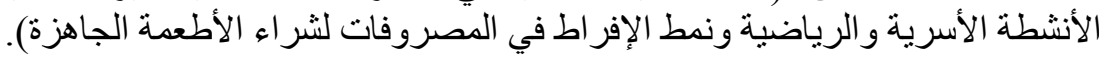

الار اسة الميدانية المبحث الأول: منهجية المبدانة الدراسة وإجراعاتها تمهيد

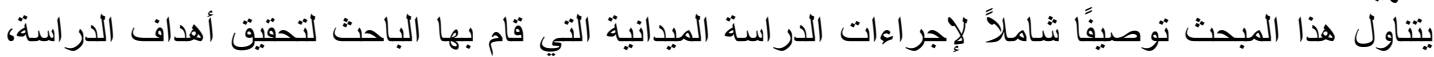

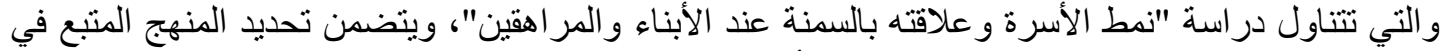

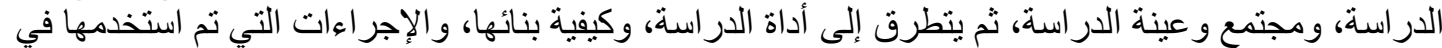

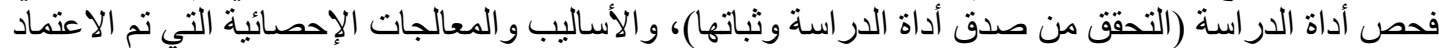
عليها في تحليل البيانات للوصول إلى النئن النيأج.

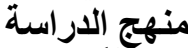

انطلاقًًاً من طبيعة الدراسة، والأهداف التي تسعى إلى تحقبقها، و البيانات المر اد الحصول عليها، وبناءً على الته

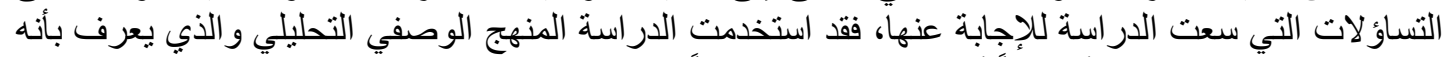

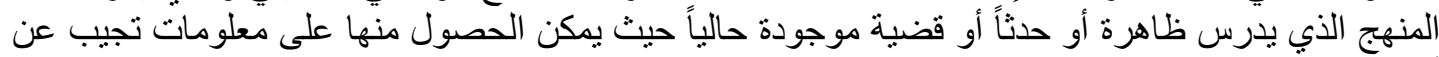
أسئلة البحثُ دون تدخل الباحث فئها.

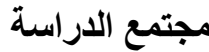
يتكون مجتمع الدر اسة من جميع الأسر التي لديها أبناء مر اهقين بمدينة جدة، بالمملكة العربية السعودية.

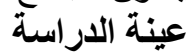
تكونت عينة الدراسة من 496 أسرة تم توزيع الاستبيان عليهم وقد تم استبعاد 92 استمارة استبيان وذللك لعدم

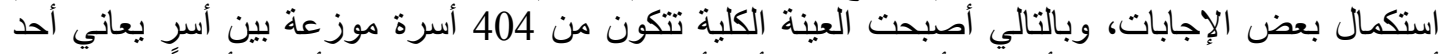

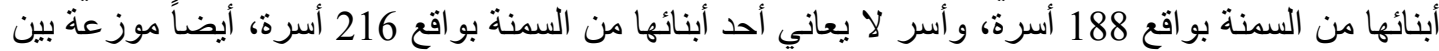

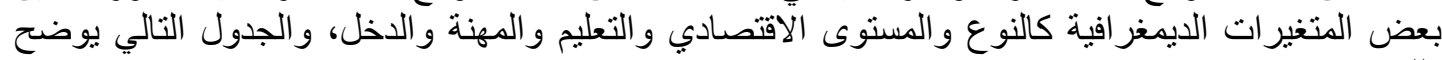




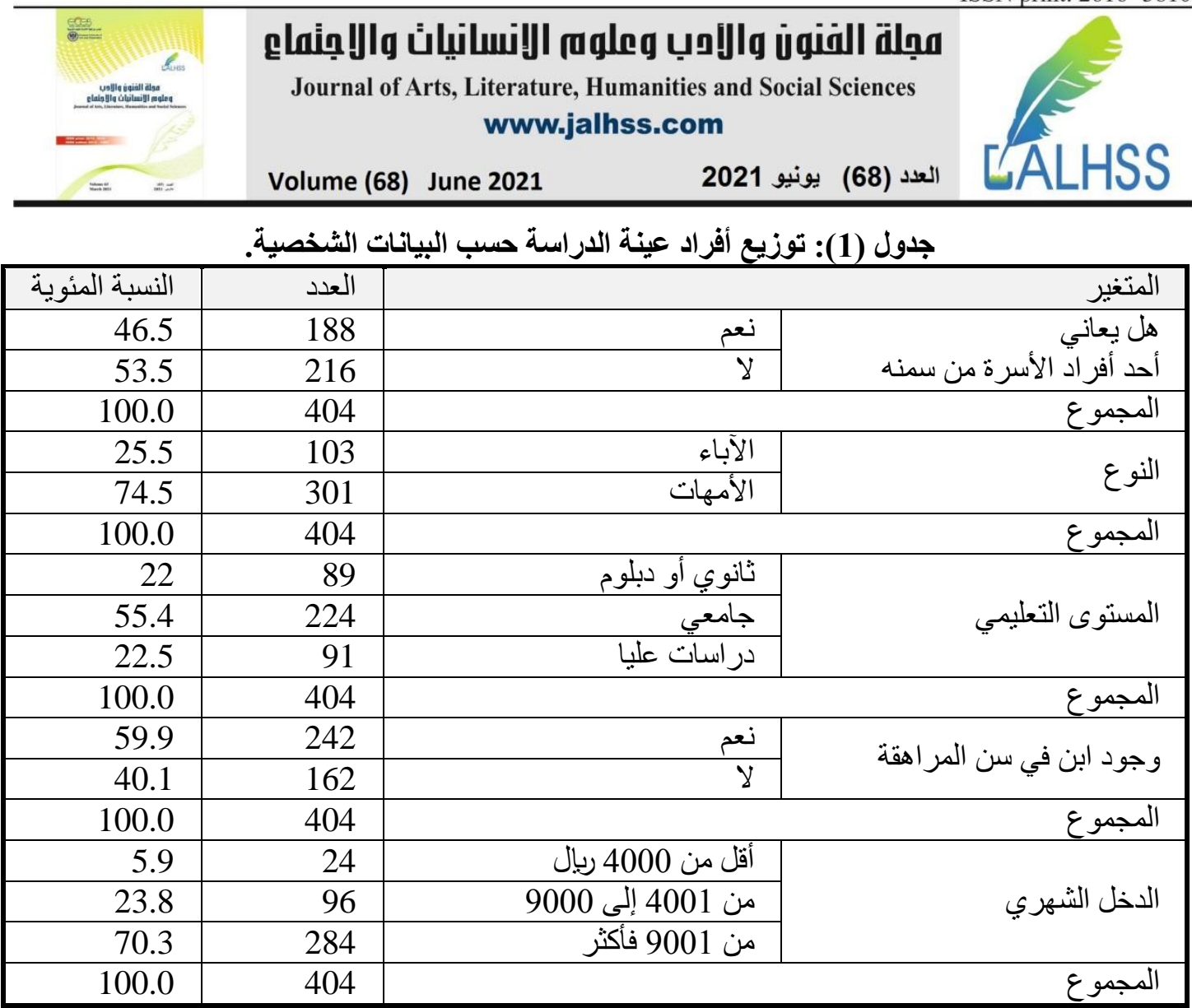

ملاحظة/ النسب بالجدول مقربة لأقرب رقم بعد الفاصلة.

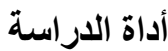
في ضوء أهداف الدراسة وأسئلتها فإن الأداة المناسبة لتحقيق أهداف الدراسة هي الاستبانة، وتم تصميمه

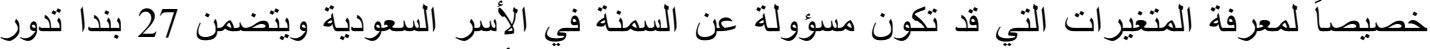
معظمها حول العادات الصحية وغير الصحية لتناول الغذاء وممارسة الأساليب الرياضية وقضاء التئية وقت الفراغ.

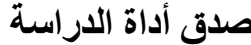

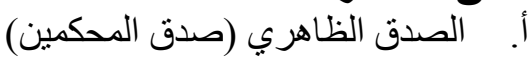

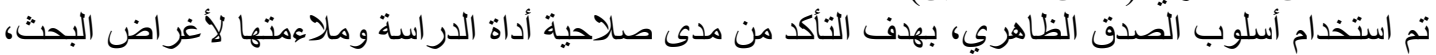

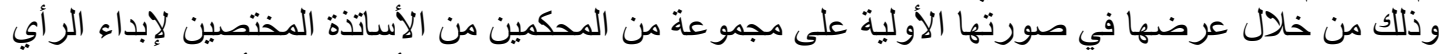

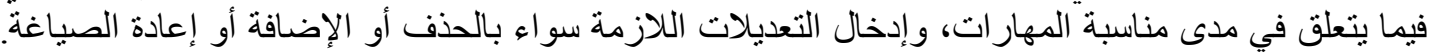

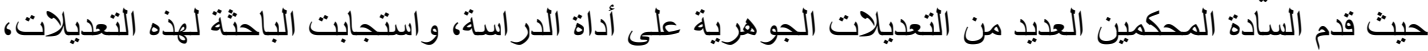
وقامت بإعادة صياغة الأداة في ضو العاد الملاحظات التي قدمها المحكمين، حتى أخذت شكلها النهائي.

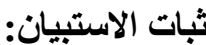
قامت الباحثة بعمل ثبات بطريقة ألفا كرونباخ Cronbach's Alpha لبنود الاستبيان و الذي بلغ 0.347 وهو

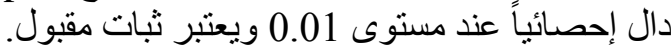

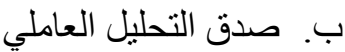

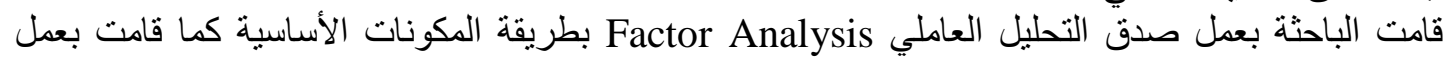

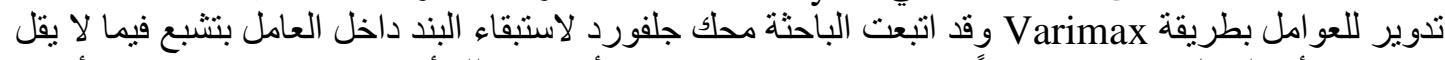

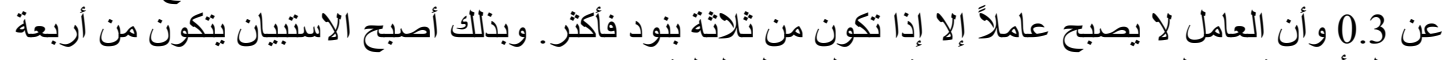
عو امل أساسية بعد التدوير، وان لإحي موضحة في الجداول التالية: 


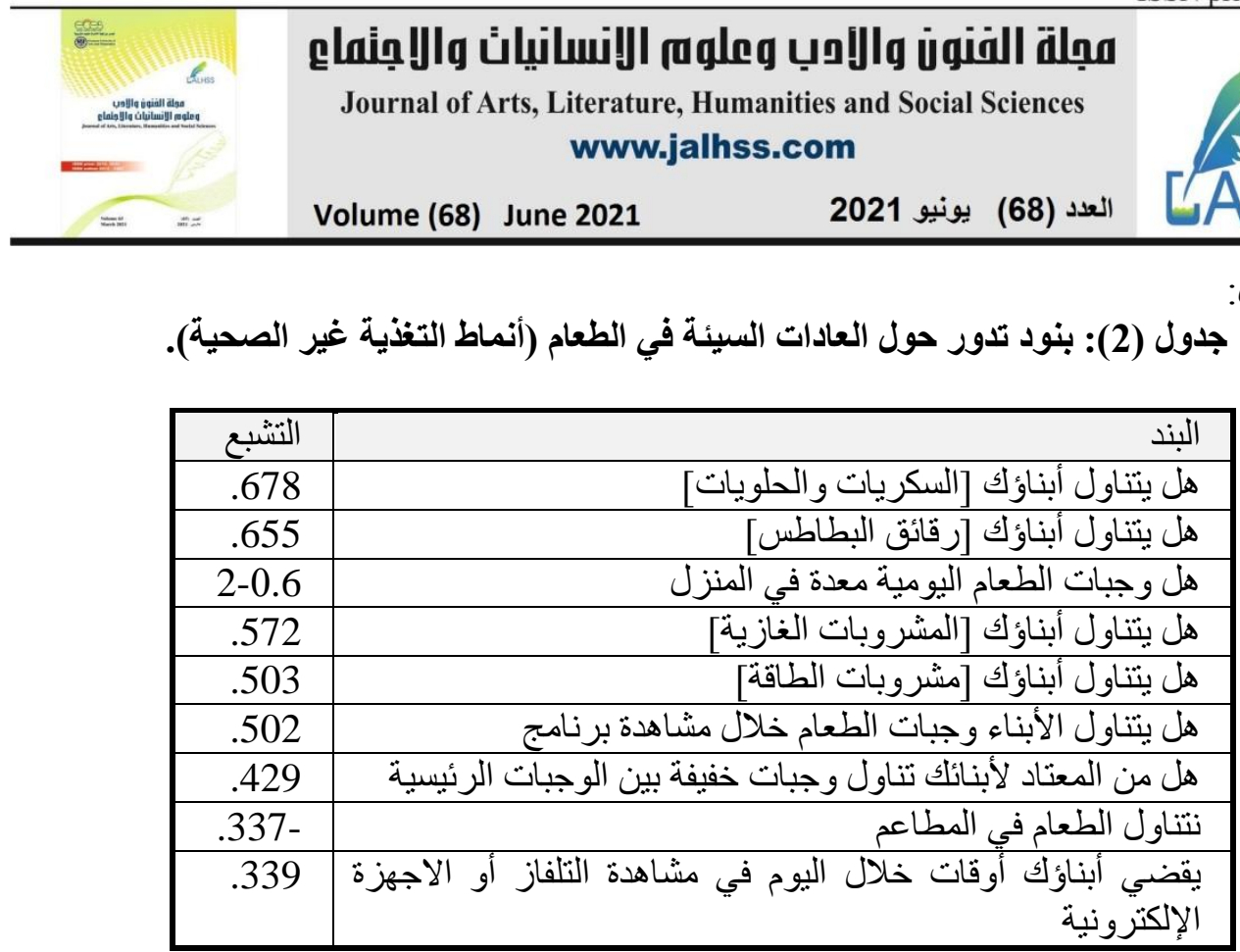

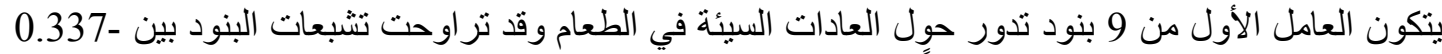

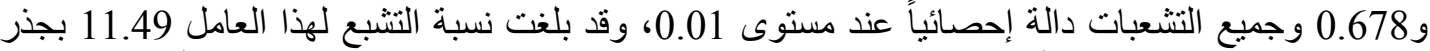

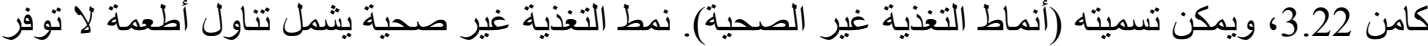

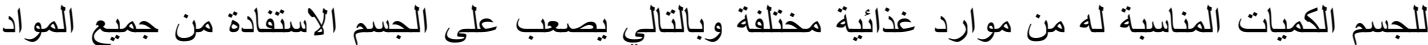

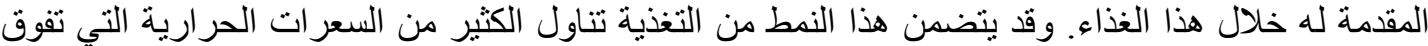

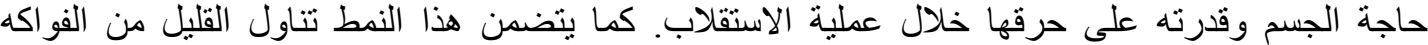

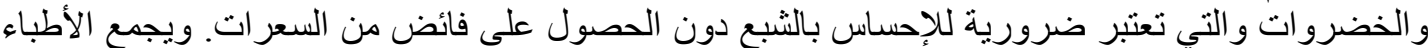

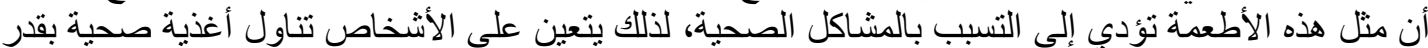

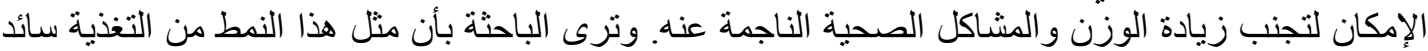

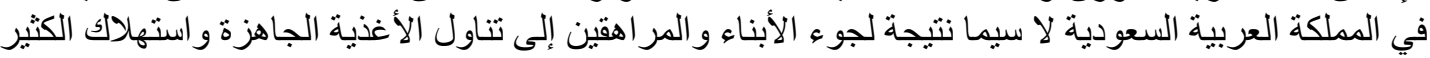

من المشروبات الغازية ومشروبات الطاقة (وز ارة الصحة، 2017، WHO, 2016). جدول (3): بنود تدور حول العادات الصحية للطعام (أنماط التظذية الصحية).

\begin{tabular}{|c|c|}
\hline التشبع & البند \\
\hline .680 & هل يتناول أبناؤك [منتجات الألبان] \\
\hline .606 & هل يتناول أبناؤك [البروتينات] \\
\hline .532 & هل يتناول أبناؤك [الخضروات] \\
\hline .508 & هل يتناول أبناؤك [الفو اكه]] \\
\hline .506 & تجتمع الأسرة لتناول الطعام \\
\hline .454 & اقضي مع أبنائي وقتتاً \\
\hline .399 & هل تعتبر وجبة الإفطار أساسية للأبناء \\
\hline
\end{tabular}

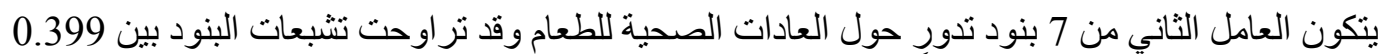

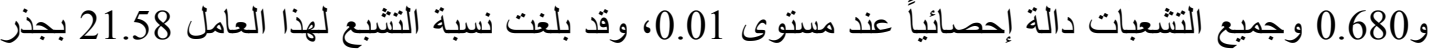
كامن 2.83 ويمكن تسميته (أنماط التغذية الصحية). ويشمل نمط التغذية الصية الصحية تناول أطعمة غنية بالعناصر

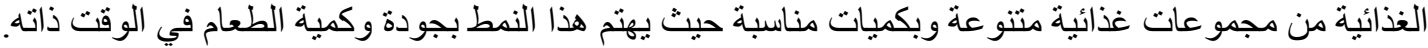

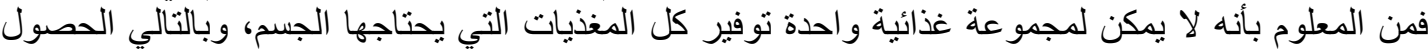

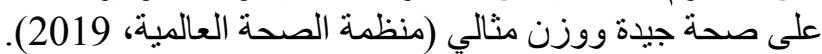




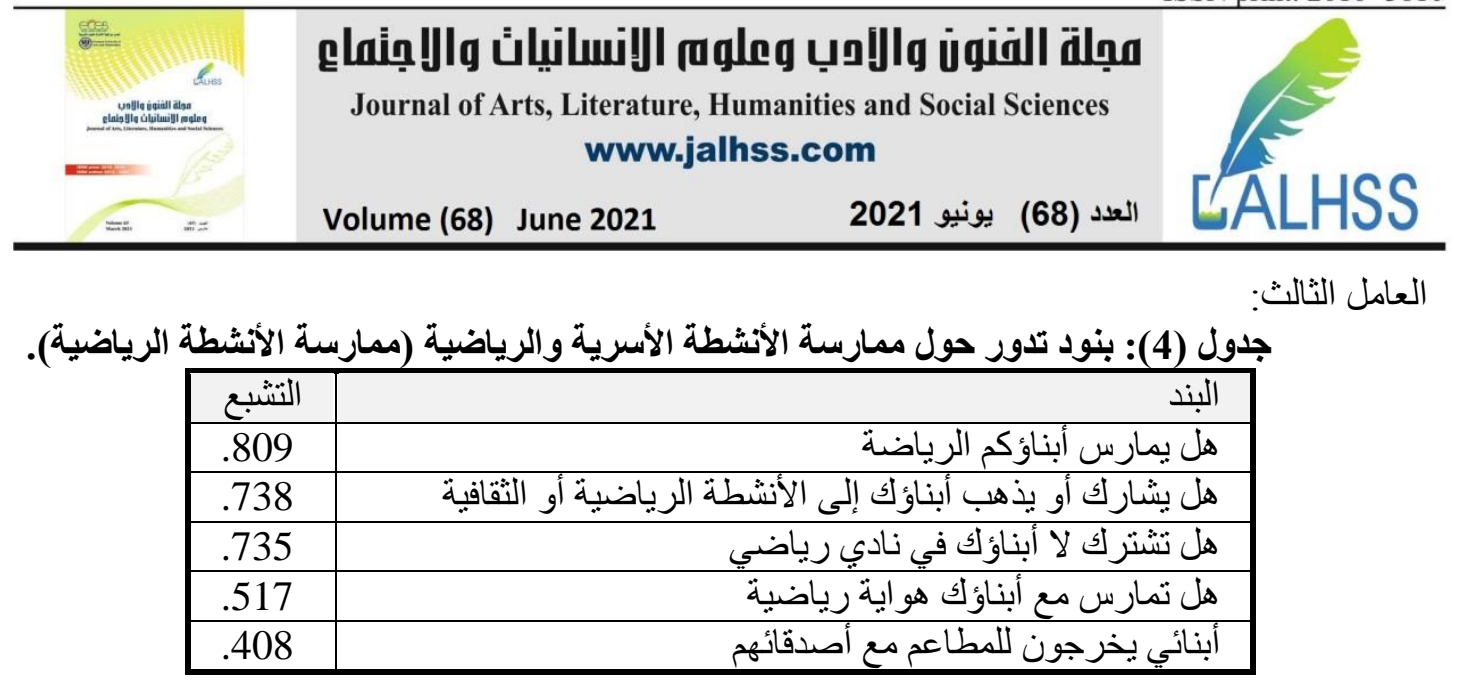

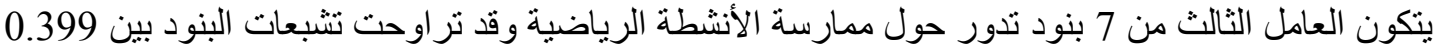

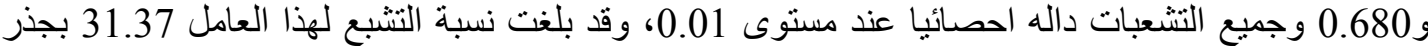

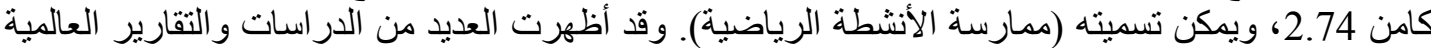

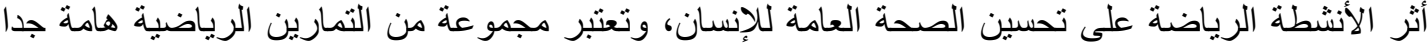

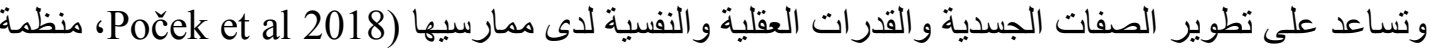

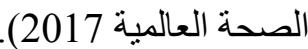

جدول (5): بنود تدور حول شر اء الأطعمة الجاهزة (الإفراط في المصروفات لثر اء الأطعمة الجاهزة).

\begin{tabular}{|c|c|}
\hline التشبع & البند \\
\hline .660 & كل و احد من أفر اد الأسرة يشتري الطعام الذب يحبه \\
\hline $.567-$ & أوفر لأبنائي مصروف خاص لشر اء الأطعمة التي يحبونها \\
\hline .498 & أوفر لأبنائي مصروف للخروج مع اصدقائهم \\
\hline .440 & أعطي أبنائي مصروف \\
\hline
\end{tabular}

ينكون العامل الر ابع من 4 بنود تدور حول شر اء الأطعمة الجاهزة وقد نراوحت تثبعات البنود بين 0.399

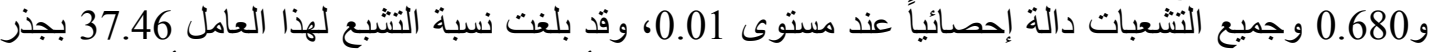

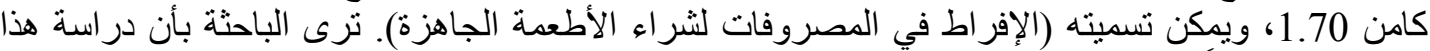

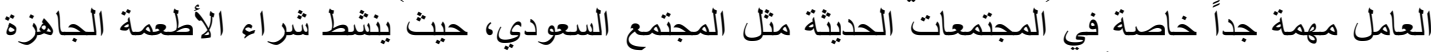

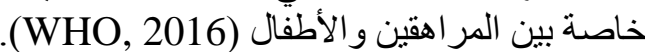

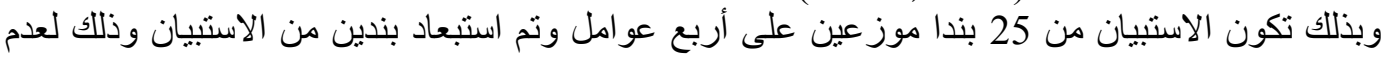

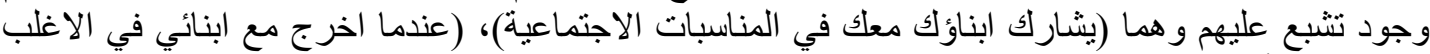

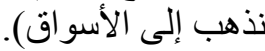

\section{الأساليب الإحصائية المستخدمة في معالجة البيانات:}

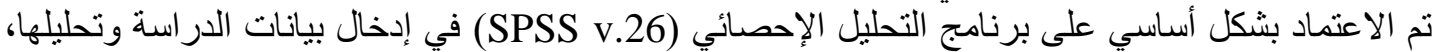

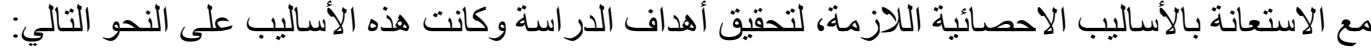

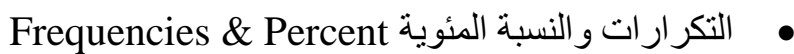

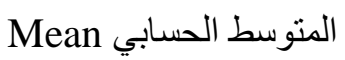

لانحر اف المعياري Standard Deviation

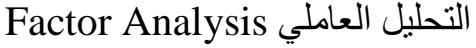

اختبار "ت" لعينتين مستقلتين التين T-test

ANOVA اختبار تحليل التبارين 


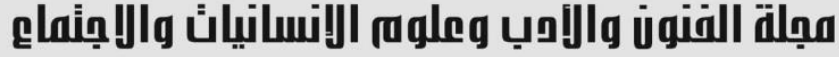

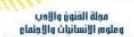

Journal of Arts, Literature, Humanities and Social Sciences

www.jalhss.com

Volume (68) June 2021

العدد (68) يونيو 2021

LALLHSS

\section{المبحث الثاني: تحليل النتائج والإجابة عن التساؤلات}

بتناول هذا المبحث عرض وتحليل لأهم النتائج الإحصائية التي تم التوصل إليها حول مشكلة الدراسة و التي

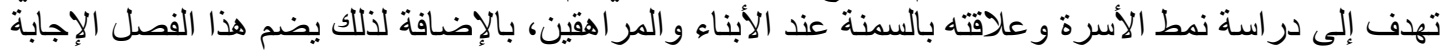

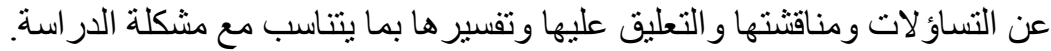
الإجابة عن تساؤ لات الدر استة: 1. هل تختلف أنماط السمنة عند الأبناء والمر اهقين باختلاف متغير النوع (الآباء- الأمهات) على عوامل الاستبيان الأربعة و الدرجة الكلية؟ الإنج للإجابة عن هذا التساؤل قامت الباحثة بحساب التكرار ات التانة والنسب المئوية، واختبار "ت" لعينتين مستقلتنين لمعرفة الفروق بين الذكور و الإناث على أنماط استبيان السمنة، فكانت النتائج على النحو التالي:

جدول (6) يوضح تباين النسبة المئوية لأنماط السمنة المختلفة لدى الأكور والإناث على عامل أنماط التغذية غير الصحية

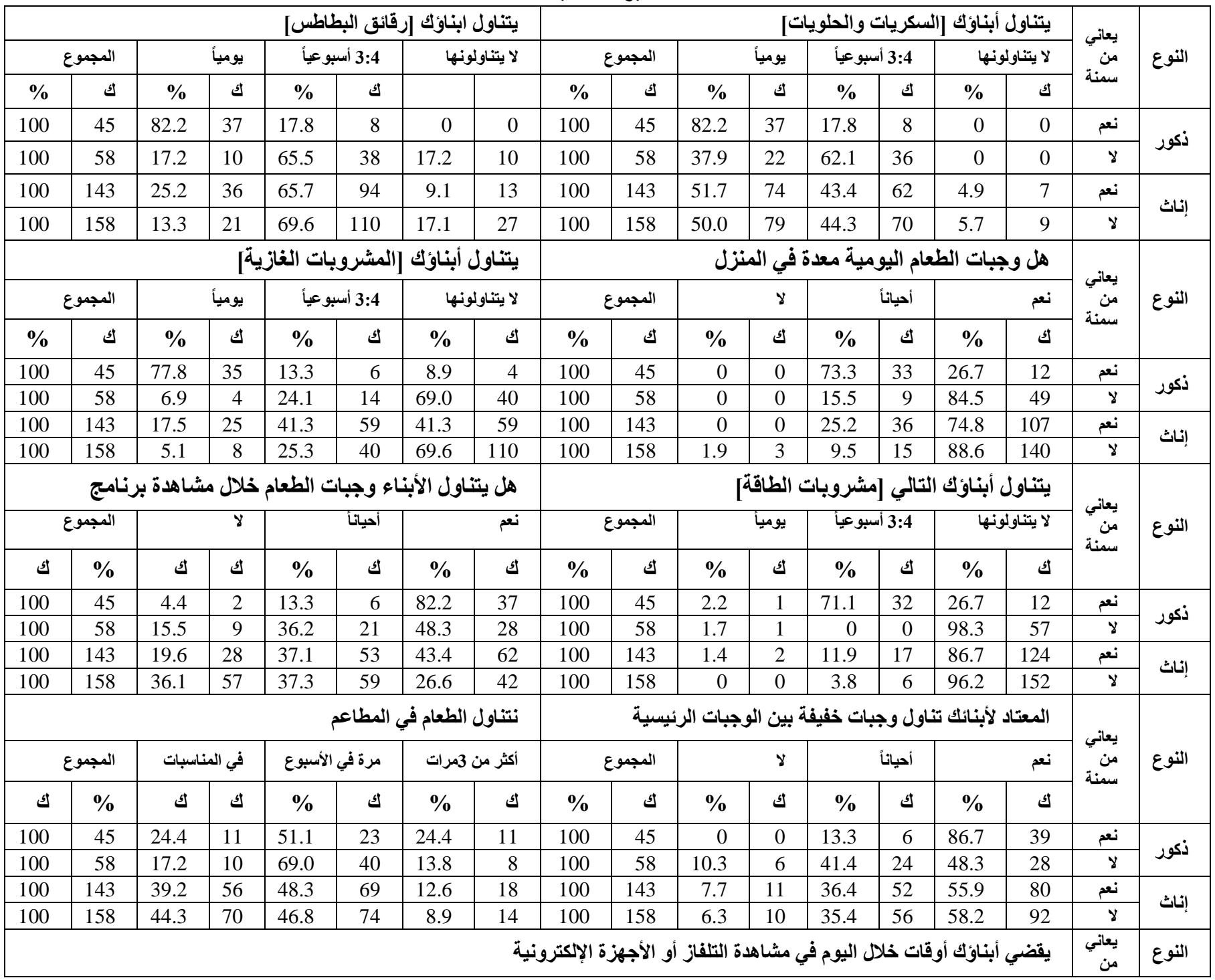




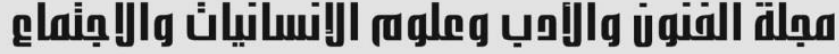

Journal of Arts, Literature, Humanities and Social Sciences

www.jalhss.com

Volume (68) June 2021

[A/ALHSS

\begin{tabular}{|c|c|c|c|c|c|c|c|c|c|c|c|}
\hline \multicolumn{2}{|c|}{ المجموع } & \multicolumn{2}{|c|}{ كثيراً } & \multicolumn{2}{|c|}{ ساعات محددة } & \multicolumn{2}{|c|}{ ن نادراً } & \multicolumn{2}{|r|}{ قليلاً } & \multirow[t]{2}{*}{ سمنة } & \\
\hline$\%$ & ك & $\%$ & s] & ك & $\%$ & $\%$ & ك & $\%$ & ك & & \\
\hline 100 & 45 & 75.6 & 34 & 20.0 & 9 & 2.2 & 1 & 2.2 & 1 & نعم & زكر \\
\hline 100 & 58 & 56.9 & 33 & 31.0 & 18 & 5.2 & 3 & 6.9 & 4 & $\gamma$ & دكور \\
\hline 100 & 143 & 82.5 & 118 & 11.2 & 16 & 1.4 & 2 & 4.9 & 7 & نعم & \\
\hline 100 & 158 & 53.2 & 84 & 34.2 & 54 & 1.9 & 3 & 10.8 & 17 & $\gamma$ & \\
\hline
\end{tabular}

جدول (7) يوضح تباين النسبة المئوية لأنماط السمنة المختلفة لدى الأكور والإناث على عامل أنماط التغذية الصحية

\begin{tabular}{|c|c|c|c|c|c|c|c|c|c|c|c|c|c|c|c|c|c|}
\hline \multicolumn{8}{|c|}{ هل يتناول أبناؤك [البروتينات] } & \multicolumn{8}{|c|}{ هل يتناول أبناؤك [منتجات الألبان] } & \multirow{3}{*}{ سمنة يعني } & \multirow{3}{*}{ النوع } \\
\hline \multicolumn{2}{|c|}{ المجموع } & \multicolumn{2}{|r|}{ 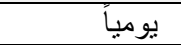 } & \multicolumn{2}{|c|}{ 3:4 أسبو عياً } & \multicolumn{2}{|c|}{ لا يتناولونها } & \multicolumn{2}{|c|}{ المجموع } & \multicolumn{2}{|c|}{ 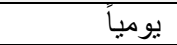 } & \multicolumn{2}{|c|}{ 3:4 أسبو عياً } & \multicolumn{2}{|c|}{ لا يتناولونها } & & \\
\hline$\%$ & 5 & $\%$ & 5 & $\%$ & 5 & $\%$ & ك & $\%$ & 5 & $\%$ & 5 & $\%$ & 5 & $\%$ & 5 & & \\
\hline 100 & 45 & 2.2 & 1 & 88.9 & 40 & 8.9 & 4 & 100 & 45 & 6.7 & 3 & 91.1 & 41 & 2.2 & 1 & نعم & \multirow{2}{*}{ ذكور } \\
\hline 100 & 58 & 43.1 & 25 & 53.4 & 31 & 3.4 & 2 & 100 & 58 & 56.9 & 33 & 41.4 & 24 & 1.7 & 1 & $\bar{\gamma}$ & \\
\hline 100 & 143 & 54.5 & 78 & 41.3 & 59 & 4.2 & 6 & 100 & 143 & 51.7 & 74 & 44.1 & 63 & 4.2 & 6 & نعم & \multirow{2}{*}{ إناث } \\
\hline 100 & 158 & 63.9 & 101 & 34.2 & 54 & 1.9 & 3 & 100 & 158 & 64.6 & 102 & 33.5 & 53 & 1.9 & 3 & ע & \\
\hline \multicolumn{8}{|c|}{ هل يتناول أبناؤك [الفو اكه]] } & \multicolumn{8}{|c|}{ هل يتناول أبناؤك [الخضروات] } & يعاني & \multirow{3}{*}{ النوع } \\
\hline \multicolumn{2}{|c|}{ المجموع } & \multicolumn{2}{|r|}{ يومياً } & \multicolumn{2}{|c|}{ 3:4 أسبو عياً } & \multicolumn{2}{|c|}{ لا يتناولونها } & \multicolumn{2}{|c|}{ المجموع } & \multicolumn{2}{|r|}{ يومياً ت بوياً } & 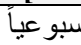 & & \multicolumn{2}{|c|}{ لا يتناولونها } & من & \\
\hline$\%$ & 5 & $\%$ & ك & $\%$ & 5 & $\%$ & 5 & $\%$ & 5 & $\%$ & 5 & $\%$ & ك5 & $\%$ & 5 & سمنة & \\
\hline 100 & 45 & 4.4 & 2 & 93.3 & 42 & 2.2 & 1 & 100 & 45 & 4.4 & 2 & 31.1 & 14 & 64.4 & 29 & نعم & \multirow[b]{2}{*}{ ذكور } \\
\hline 100 & 58 & 20.7 & 12 & 74.1 & 43 & 5.2 & 3 & 100 & 58 & 25.9 & 15 & 63.8 & 37 & 10.3 & 6 & $y$ & \\
\hline 100 & 143 & 13.3 & 19 & 66.4 & 95 & 20.3 & 29 & 100 & 143 & 19.6 & 28 & 60.8 & 87 & 19.6 & 28 & نعم & \multirow{2}{*}{ إناث } \\
\hline 100 & 158 & 31.0 & 49 & 62.7 & 99 & 6.3 & 10 & 100 & 158 & 39.2 & 62 & 40.5 & 64 & 20.3 & 32 & $\bar{y}$ & \\
\hline & & & & & وقتا & مع ابنا & & & & & & & ول الص & لأسرة لر & تجتم & يعانى & \\
\hline & & & المجم & & كثير أ & & قليلا & & المجد & & من5 & فأقَّل & & & يو ميا & من & النوع \\
\hline & & $\%$ & ك & $\%$ & ك & $\%$ & ك & $\%$ & ك & $\%$ & 5 & $\%$ & ك) & $\%$ & ك & سمنة & \\
\hline & & 100 & 45 & 8.9 & 4 & 91.1 & 41 & 100 & 45 & 33.3 & 15 & 60.0 & 27 & 6.7 & 3 & نعم & ن \\
\hline & & 100 & 58 & 43.1 & 25 & 56.9 & 33 & 100 & 58 & 22.4 & 13 & 5.2 & 3 & 72.4 & 42 & $y$ & دحور \\
\hline & & 100 & 143 & 76.2 & 109 & 23.8 & 34 & 100 & 143 & 18.9 & 27 & 25.9 & 37 & 55.2 & 79 & نعم & \\
\hline & & 100 & 158 & 75.3 & 119 & 24.7 & 39 & 100 & 158 & 17.7 & 28 & 12.0 & 19 & 70.3 & 111 & $\bar{y}$ & إنات \\
\hline & & & & & & & & & & & & لاسية لر & فظار & روجبة & هل ت & يعاني & \\
\hline & & & & & & & & & الدج: & & لا أو & & תح & & مو اففٍ & من & النوع \\
\hline & & & & & & & & $\%$ & 5 & $\%$ & 5 & $\%$ & 5 & $\%$ & 5 & سمنة & \\
\hline & & & & & & & & 100 & 45 & 11.1 & 5 & 26.7 & 12 & 62.2 & 28 & نعم & \\
\hline & & & & & & & & 100 & 58 & 6.9 & 4 & 10.3 & 6 & 82.8 & 48 & $y$ & دحور \\
\hline & & & & & & & & 100 & 143 & 8.4 & 12 & 20.3 & 29 & 71.3 & 102 & نعم & l \\
\hline & & & & & & & & 100 & 158 & 6.3 & 10 & 14.6 & 23 & 79.1 & 125 & $\gamma$ & إنات \\
\hline
\end{tabular}




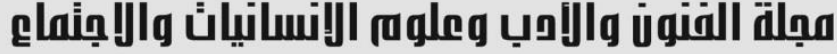 \\ Journal of Arts, Literature, Humanities and Social Sciences www.jalhss.com}

Volume (68) June 2021

العدد (68) يونيو 2021

LALHSS

جدول (8) يوضح تباين النسبة المئوية لأنماط السمنة المختلفة لاى الذكور والإناث على عامل ممارسة الأنثطة الرياضية

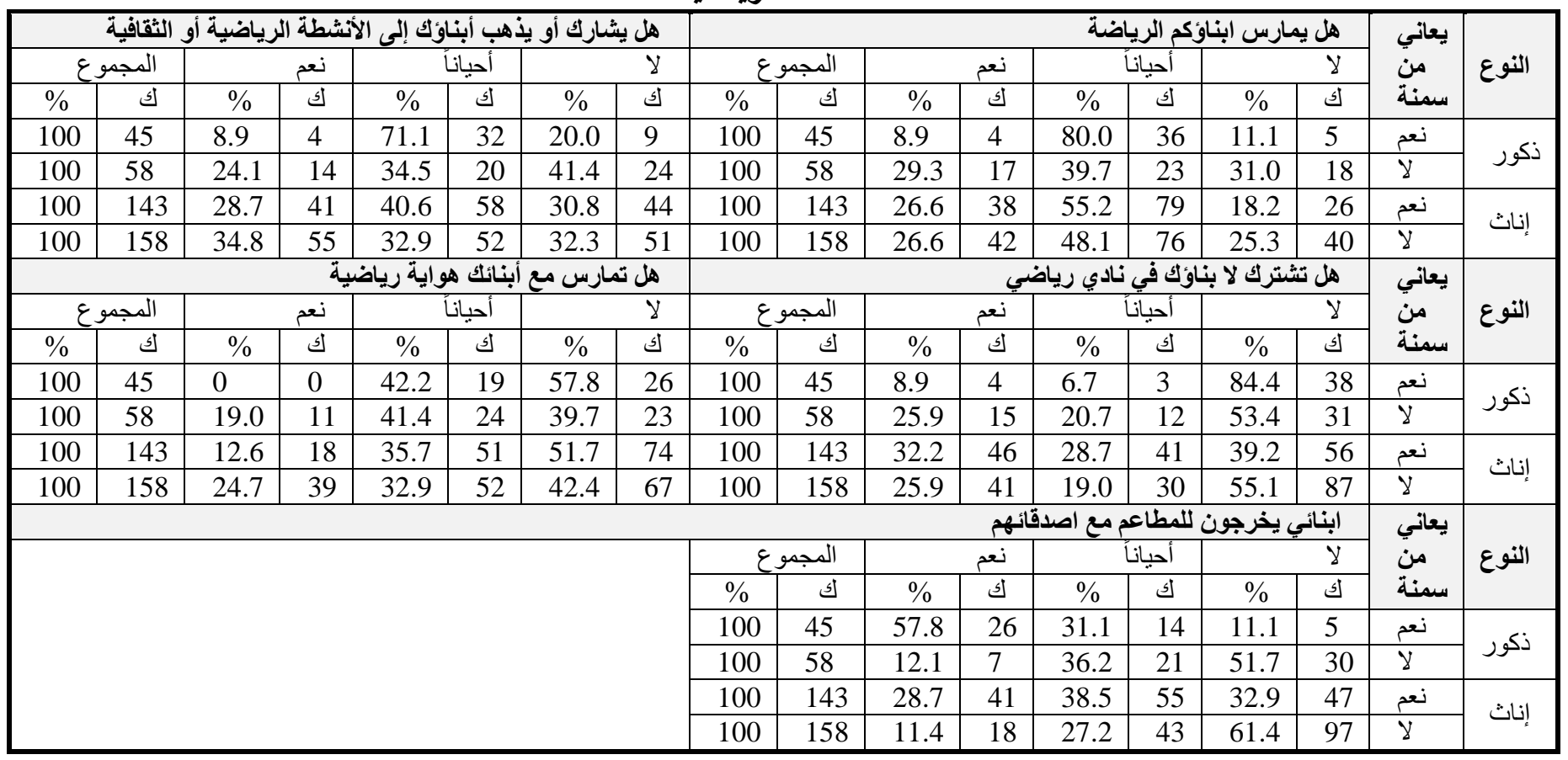

جدول (9) يوضح تباين النسبة المئوية لأنماط السمنة المختلفة لدى الأكور والإناث على عامل الإفراط في

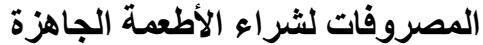

\begin{tabular}{|c|c|c|c|c|c|c|c|c|c|c|c|c|c|c|c|c|c|}
\hline \multicolumn{8}{|c|}{ أوفر لأبنائي مصروف خاص لثراء الأطعمة التي يحبونها } & \multicolumn{8}{|c|}{ كل واحل من أفراد الأسرة يشتري الطعام الذي يحبه } & \multirow{3}{*}{ سمنة } & \multirow{3}{*}{ 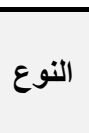 } \\
\hline \multicolumn{2}{|c|}{ 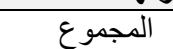 } & \multicolumn{2}{|c|}{ أوفره بالمنزل } & \multicolumn{2}{|c|}{$\gamma$} & \multicolumn{2}{|c|}{ نعم } & \multicolumn{2}{|c|}{ المجموع } & \multicolumn{2}{|c|}{ نعم } & \multicolumn{2}{|c|}{ أحياناً } & \multicolumn{2}{|c|}{$y$} & & \\
\hline$\%$ & 5 & $\%$ & ك & $\%$ & ك & $\%$ & s & $\%$ & 5 & $\%$ & ك & $\%$ & ك & $\%$ & 5 & & \\
\hline 100 & 45 & 55.6 & 25 & 11.1 & 5 & 33.3 & 15 & 100 & 45 & 28.9 & 13 & 57.8 & 26 & 13.3 & 6 & نعم & \multirow[b]{2}{*}{ ذكور } \\
\hline 100 & 58 & 67.2 & 39 & 13.8 & 8 & 19.0 & 11 & 100 & 58 & 34.5 & 20 & 27.6 & 16 & 37.9 & 22 & ע & \\
\hline 100 & 143 & 44.1 & 63 & 18.2 & 26 & 37.8 & 54 & 100 & 143 & 38.5 & 55 & 44.8 & 64 & 16.8 & 24 & نعم & \multirow{2}{*}{ إناث } \\
\hline 100 & 158 & 62.7 & 99 & 12.7 & 20 & 24.7 & 39 & 100 & 158 & 39.2 & 62 & 36.1 & 57 & 24.7 & 39 & $\bar{y}$ & \\
\hline \multicolumn{8}{|c|}{ أعطي أبنائي مصروف } & \multicolumn{8}{|c|}{ أوفر لأبنائي مصروف للخروج مع أصدقائهم } & يعاني & \multirow{3}{*}{ 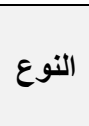 } \\
\hline \multicolumn{2}{|c|}{ المجموع ع } & \multicolumn{2}{|c|}{ حسب الطلب } & \multirow{2}{*}{\multicolumn{2}{|c|}{ دوري }} & \multicolumn{2}{|c|}{ لا أعطي } & \multicolumn{2}{|c|}{ المجموع } & \multicolumn{2}{|c|}{ نعم } & \multicolumn{2}{|c|}{ أحياناً } & \multicolumn{2}{|c|}{$\gamma$} & منّ & \\
\hline$\%$ & s & $\%$ & ك & & & $\%$ & 5 & $\%$ & 5 & $\%$ & ك & $\%$ & 5 & $\%$ & ك & سمنة & \\
\hline 100 & 45 & 15.6 & 7 & 68.9 & 31 & 15.6 & 7 & 100 & 45 & 53.3 & 24 & 28.9 & 13 & 17.8 & 8 & نعم & \multirow{2}{*}{ ذكور } \\
\hline 100 & 58 & 36.2 & 21 & 53.4 & 31 & 10.3 & 6 & 100 & 58 & 24.1 & 14 & 34.5 & 20 & 41.4 & 24 & $\bar{y}$ & \\
\hline 100 & 143 & 45.5 & 65 & 44.1 & 63 & 10.5 & 15 & 100 & 143 & 49.7 & 71 & 32.9 & 47 & 17.5 & 25 & نعم & \multirow{2}{*}{ إناث } \\
\hline 100 & 158 & 53.2 & 84 & 31.0 & 49 & 15.8 & 25 & 100 & 158 & 38.6 & 61 & 29.7 & 47 & 31.6 & 50 & $y$ & \\
\hline
\end{tabular}




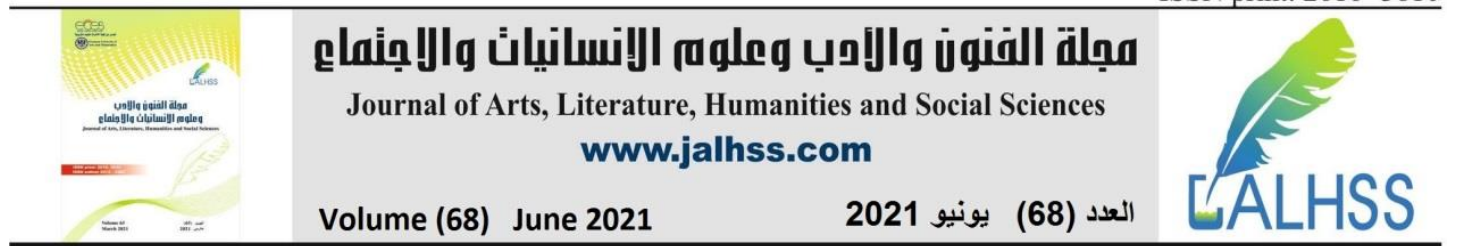

جدول (10) يوضح الفروق بين الأكور والإناث على عو امل استبيان السمنة الأربعة

\begin{tabular}{|c|c|c|c|c|c|c|}
\hline الدلالة & T.test & $\varepsilon$ & م & النوع & يعانون سمنة & العوامل \\
\hline \multirow{2}{*}{ غير دالة } & \multirow{2}{*}{8.0} & 1.951 & 24.68 & ذكور & \multirow{2}{*}{ نعم } & \multirow{4}{*}{ 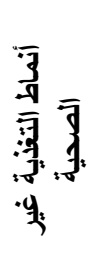 } \\
\hline & & 2.26 & 21.90 & إناث & & \\
\hline \multirow{2}{*}{ غير دالة } & \multirow{2}{*}{.051} & 2.28 & 20.75 & ذكور & \multirow{2}{*}{ ע } & \\
\hline & & 2.32 & 20.74 & إناث & & \\
\hline \multirow{2}{*}{0.001} & \multirow{2}{*}{8.16} & 1.52 & 11.00 & ذكور & \multirow{2}{*}{ نعم } & \multirow{4}{*}{ 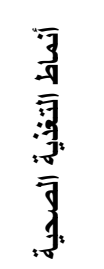 } \\
\hline & & 1.99 & 13.30 & إناث & & \\
\hline \multirow{2}{*}{0.01} & \multirow{2}{*}{2.55} & 2.08 & 16.12 & ذكور & \multirow{2}{*}{ ע } & \\
\hline & & 2.04 & 16.74 & إناث & & \\
\hline \multirow{2}{*}{0.001} & \multirow{2}{*}{9.51} & 1.80 & 12.46 & ذكور & \multirow{2}{*}{ نعم } & \multirow{4}{*}{ 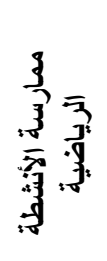 } \\
\hline & & 2.26 & 15.59 & إناث & & \\
\hline \multirow{2}{*}{0.05} & \multirow{2}{*}{1.98} & 2.08 & 16.12 & ذكور & \multirow{2}{*}{$y$} & \\
\hline & & 2.04 & 16.74 & إناث & & \\
\hline \multirow{2}{*}{ غير دالة } & \multirow{2}{*}{.83} & 1.57 & 8.73 & ذكور & \multirow{2}{*}{ نعم } & \multirow{4}{*}{ 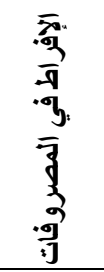 } \\
\hline & & 1.50 & 8.95 & إناث & & \\
\hline \multirow{2}{*}{ غير دالة } & \multirow{2}{*}{1.79} & 1.58 & 8.53 & ذكور & \multirow{2}{*}{$\gamma$} & \\
\hline & & 1.57 & 8.96 & إناث & & \\
\hline \multirow{2}{*}{0.01} & \multirow{2}{*}{3.84} & 3.39 & 56.88 & ذكور & \multirow{2}{*}{ نعم } & \multirow{4}{*}{ 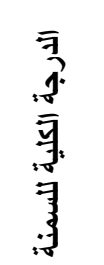 } \\
\hline & & 4.61 & 59.75 & إناث & & \\
\hline \multirow{2}{*}{0.001} & \multirow{2}{*}{2.32} & 4.81 & 58.86 & ذكور & \multirow{2}{*}{ ע } & \\
\hline & & 4.97 & 60.62 & إناث & & \\
\hline
\end{tabular}

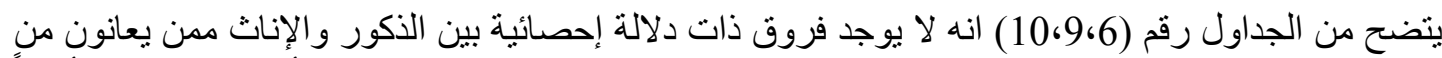

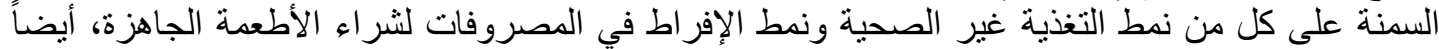

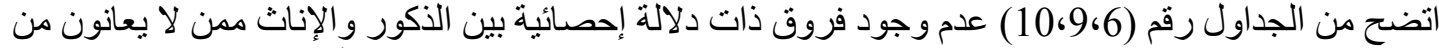

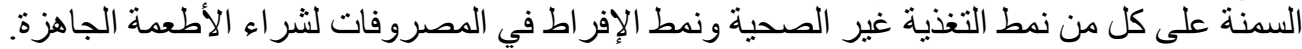

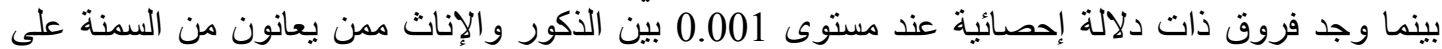

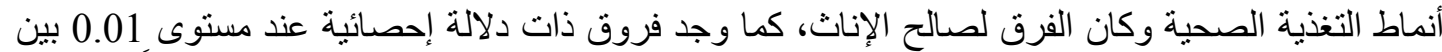

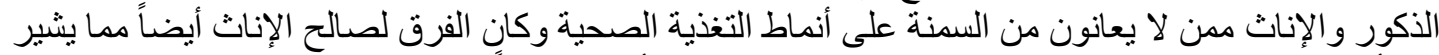

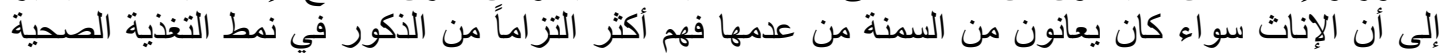
جدول (10، (10). أيضاً وجد فروق ذات دلالة إحصائية تر اوحت بين مستوى 0.001 بين الذكور و الإنات ممن يعانون من السمنة

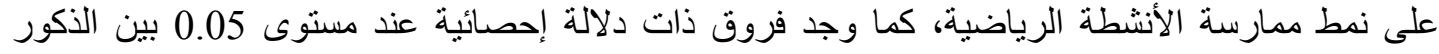




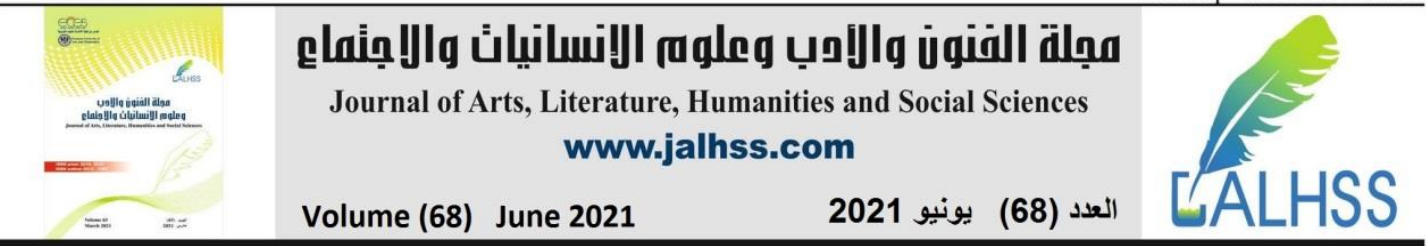

والإناث ممن لا يعانون من السمنة على نفس النمط وكان الفرق في كليهما لصالح الإناث جدول (8) 10) إضافة لذلك وجد فروق ذات دلالة إحصائية عند مسنوى السمنة ومن من لا يعانون من السمنة على الدرجة الكلية لأنماط السمنة (عو امل الاستبيان الأربعة)، وكان الأنيان الفرق

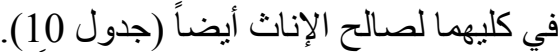

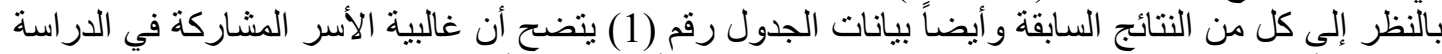

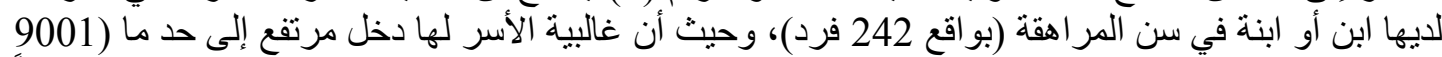

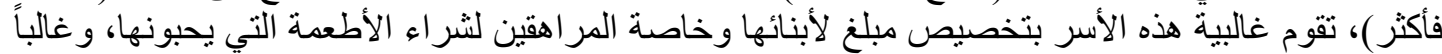

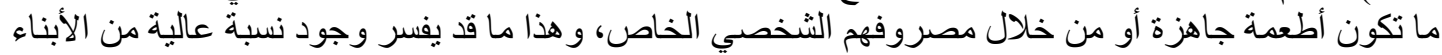

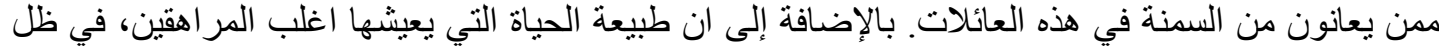

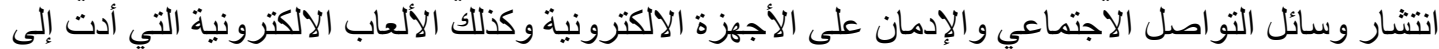

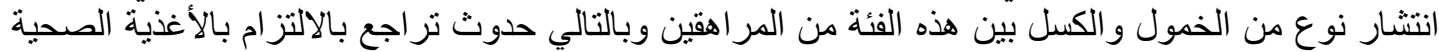

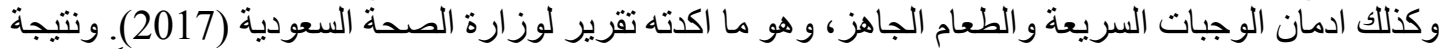

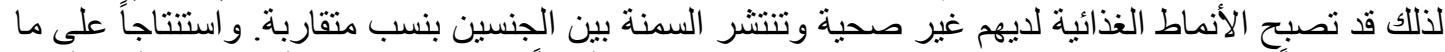

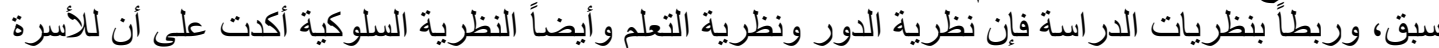

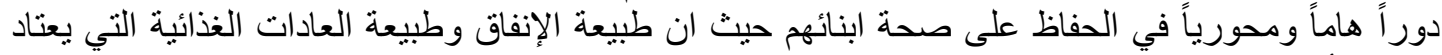

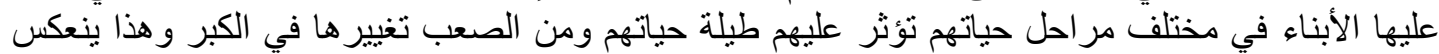

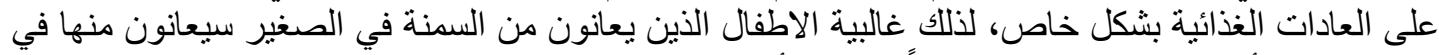

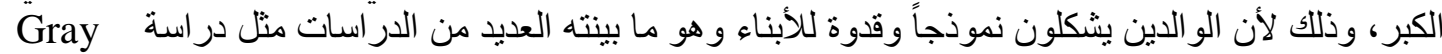

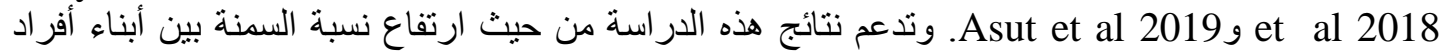

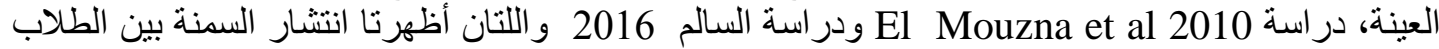
السعوديين، مما يدل زيادة استهلاك الأطعمة الجاهزة و الغيات الغير صحية.

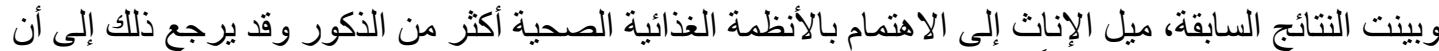

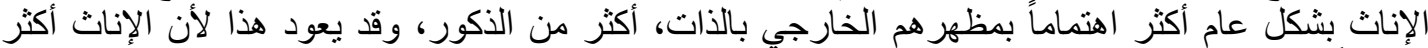

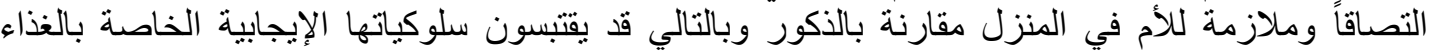

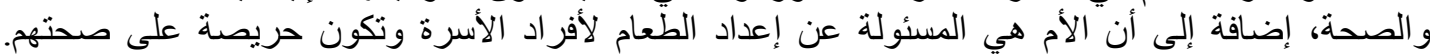

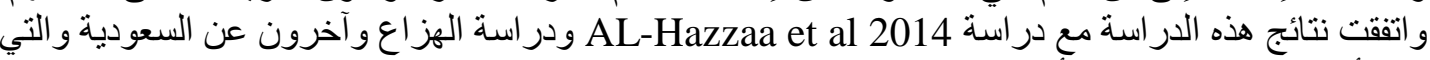
بينتا أن نسبة السمنة كانت أعلى بين الذكور عن الإناث، وكذللك اتفقت مع دراسة

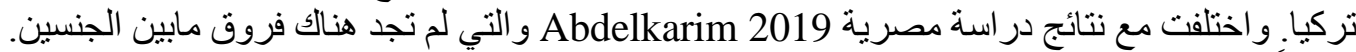

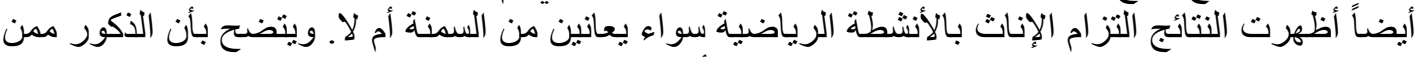

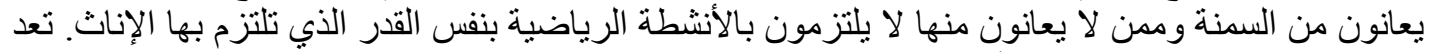

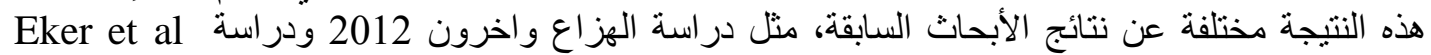

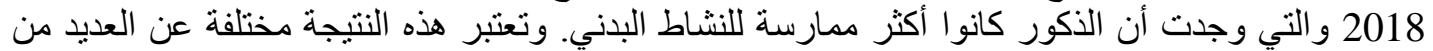

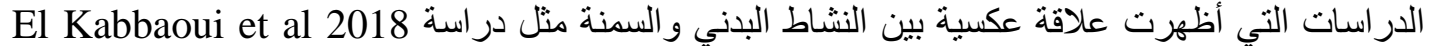

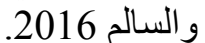

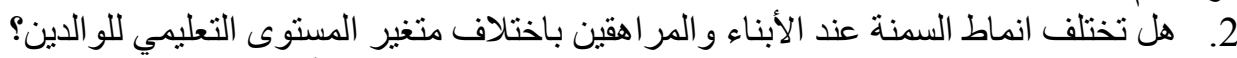

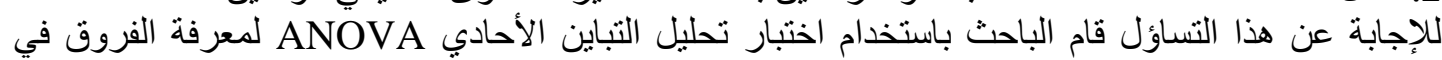
انماط السمنة عند الأبناء و المر اهقين باختلاف الئن المستوى التعليمي للو الدين، فكانت النتائج على النحو النالي: 


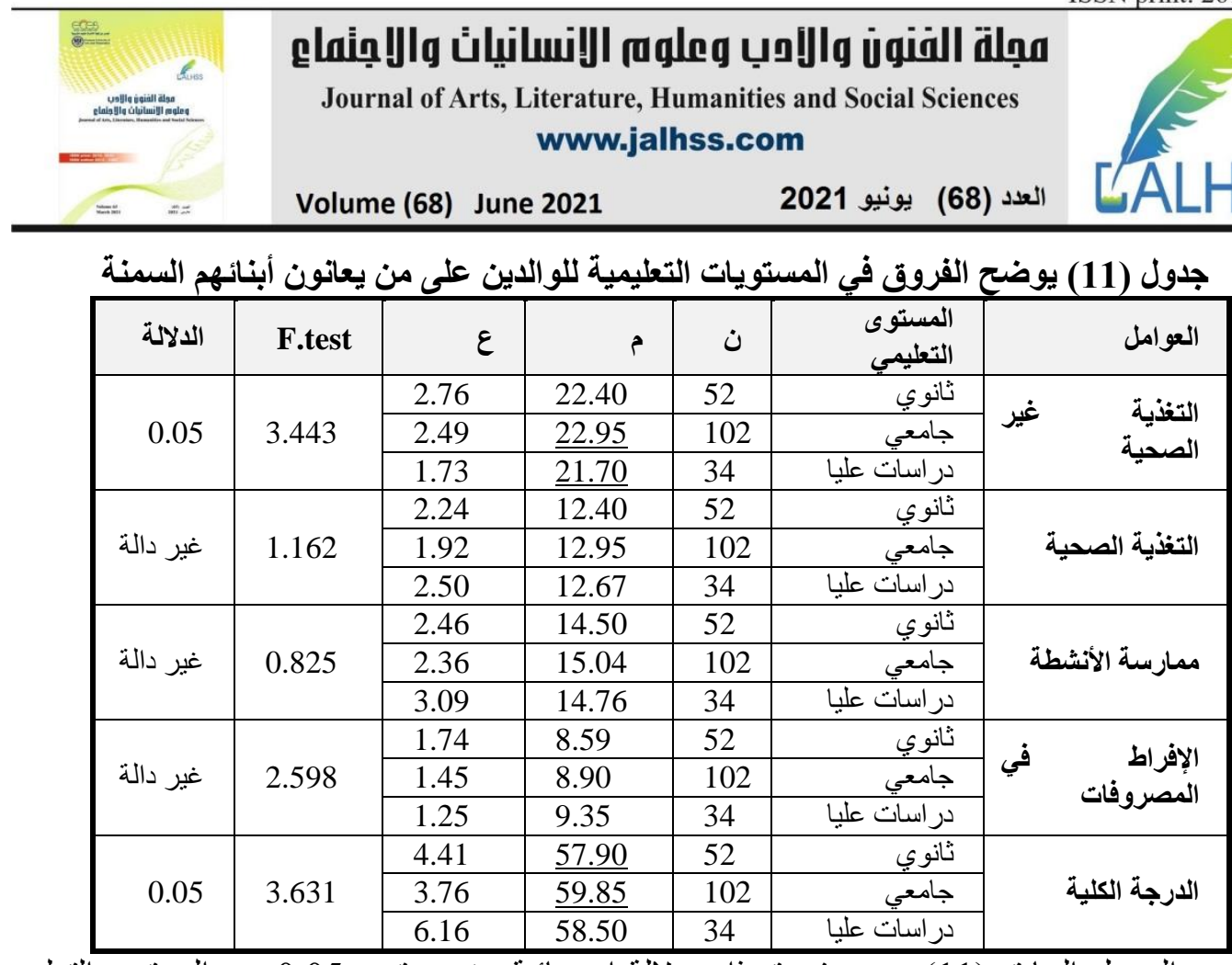

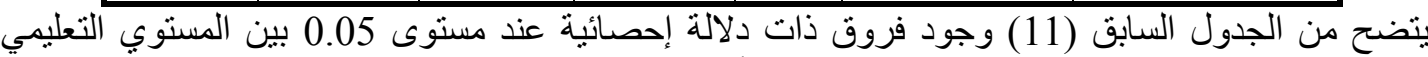

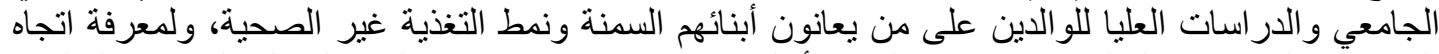

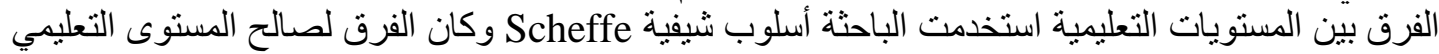

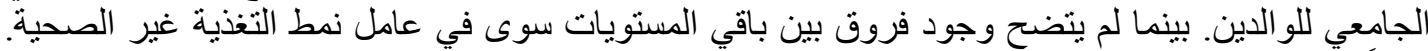

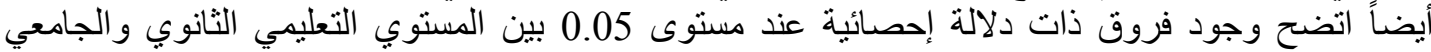

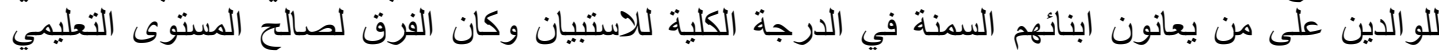

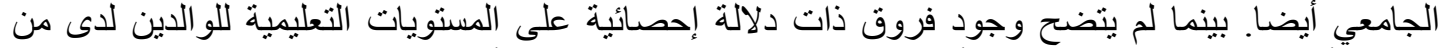

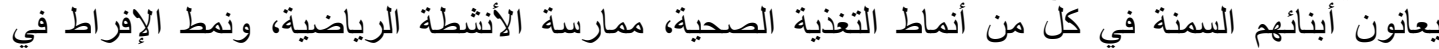
المصروفات لشراء الأطعمة الجاهزة.

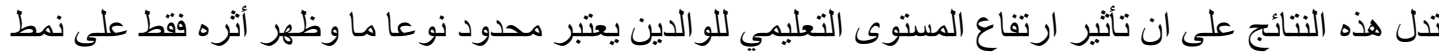

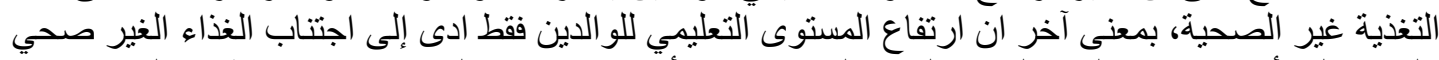

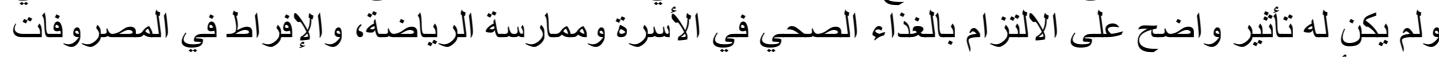

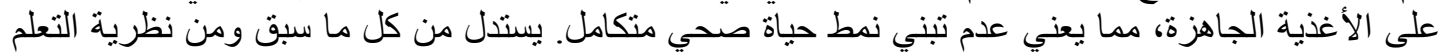

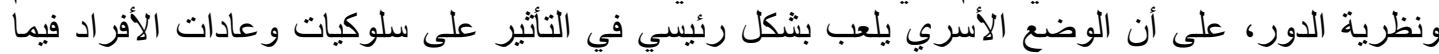

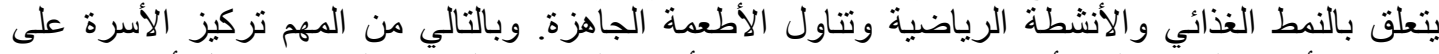

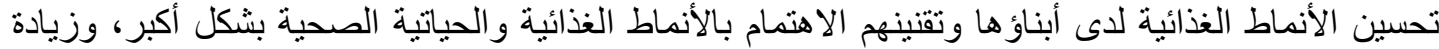

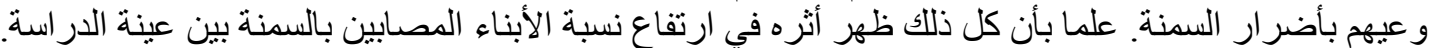

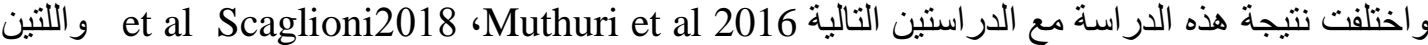
أكدتا على أن ارتفاع المستوى التعليمي للو الدين له تأثير إيجابي على تبني الأبناء نمط غذائي صحي وبالتالي تجنب سمنة الأبناء. و اتضح من نتائج الدراسة أنه لا يوجد فروق ذاتبات دلانلة إحصائية بين المستويات التعليمية للو الدين على من لا

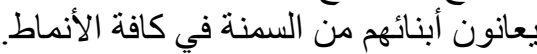
3. هل تختلف انماط السمنة عند الندة الأبناء و المر اهقين باختلاف متغير وجود ابن في مرحله المراهقة داخل

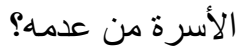

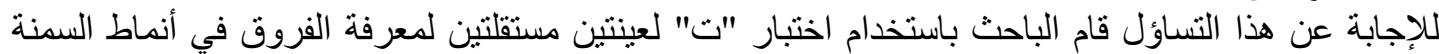
عند الأبناء و المر اهقين باختلاف متغير وجود ابن في مرحلة المر اهقة داخل الأسرة من عمده، فكانت النتائج على النحو التالي: 


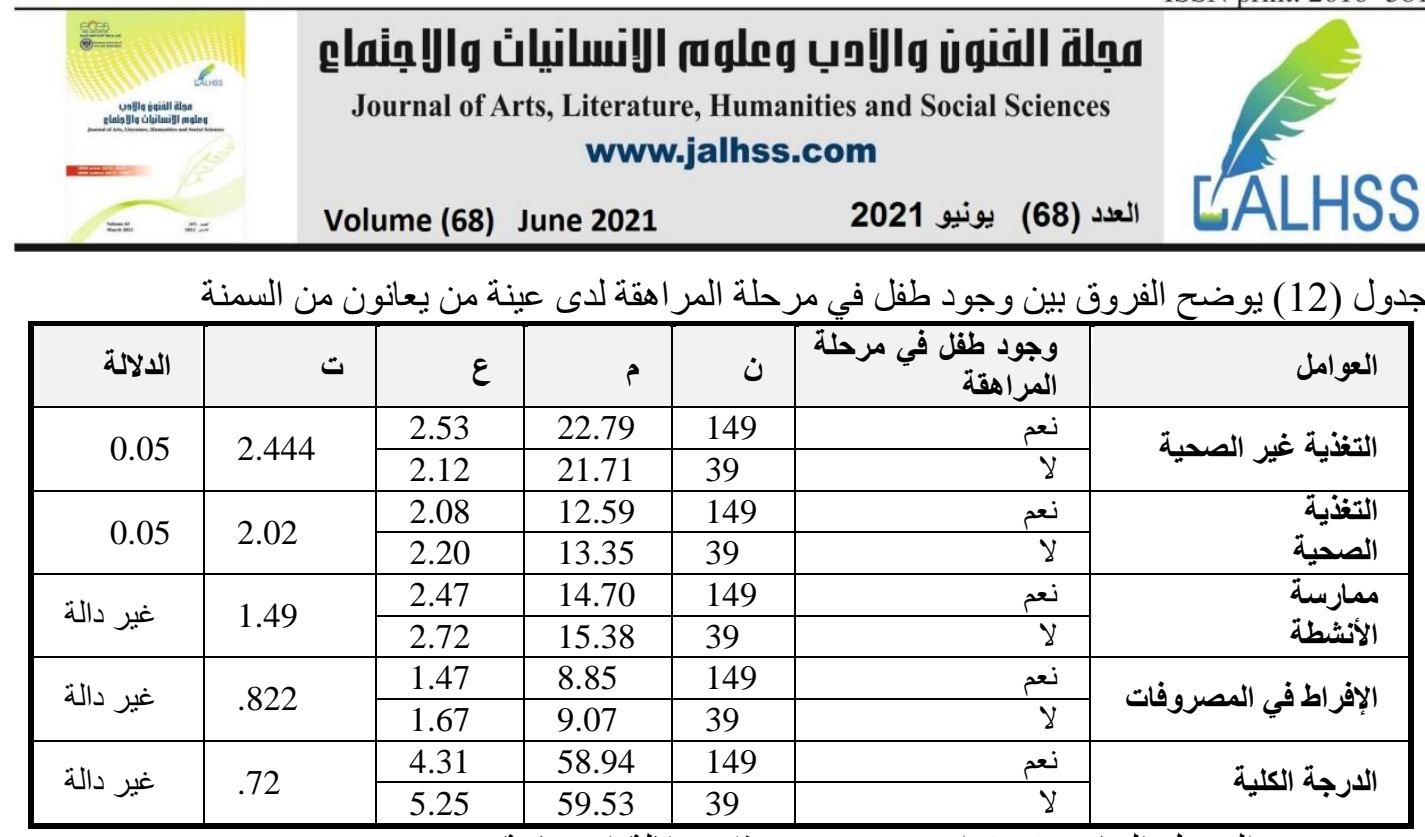

يتضح من الجدول السابق (12) انه يوجد فروق ذات دلالة إحصائية عند مستوى 0.05 بين وجود فرد في في الهي

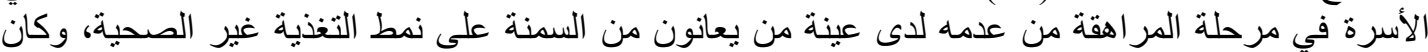

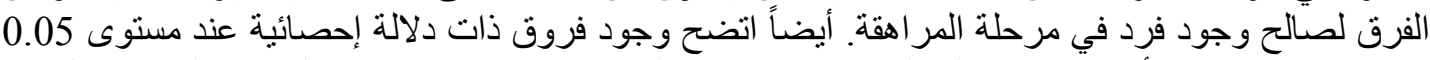

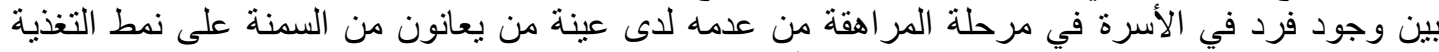

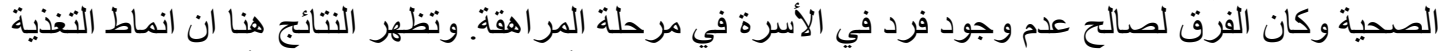

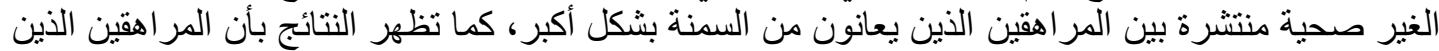

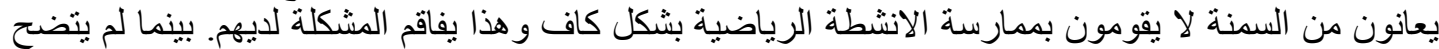

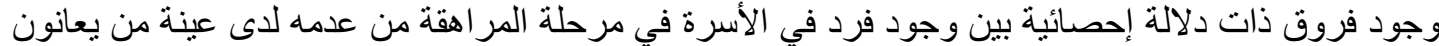

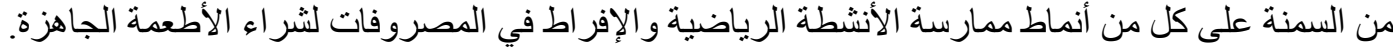

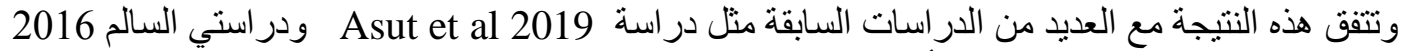

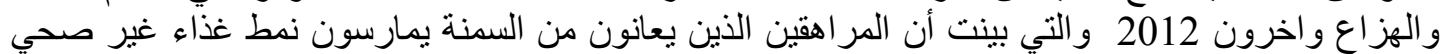

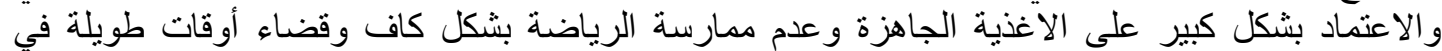

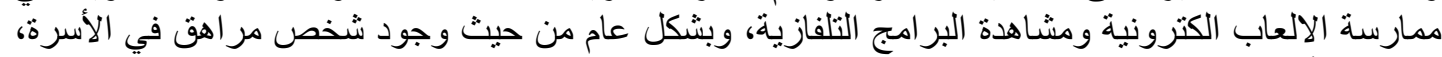

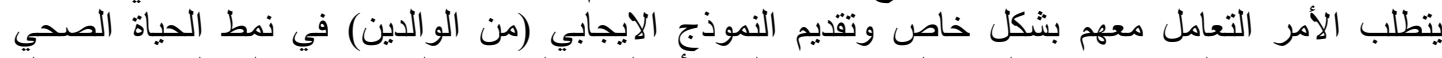

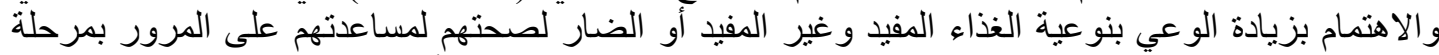

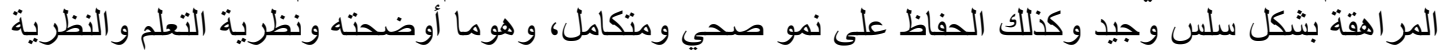

جدول (13) يوضح الفروق بين وجود طقل في مرحلة المراهقة لاى عينة من لا يعانون من السمنة

\begin{tabular}{|c|c|c|c|c|c|c|}
\hline الدلالة & $ت$ & $\varepsilon$ & r & ن ن & المراهقة طقل في مرحلة & العو امل \\
\hline \multirow{2}{*}{ غير دالة } & \multirow{2}{*}{1.233} & 2.25 & 20.96 & 93 & نعم & \multirow{2}{*}{ التظذية غير الصحية } \\
\hline & & 2.33 & 20.57 & 123 & $\gamma$ & \\
\hline \multirow{2}{*}{ غير دالة } & \multirow{2}{*}{.488 } & 1.93 & 14.04 & 93 & نعم & \multirow{2}{*}{ التظذية الصحية } \\
\hline & & 1.78 & 13.91 & 123 & $y$ & \\
\hline \multirow{2}{*}{ غبر دالة } & \multirow{2}{*}{.519 } & 2.18 & 16.49 & 93 & نعم & \multirow{2}{*}{ ممارسة الأتثطة } \\
\hline & & 1.97 & 16.64 & 123 & $y$ & \\
\hline \multirow{2}{*}{0.05} & \multirow{2}{*}{2.619} & 1.31 & 9.17 & 93 & نعم & \multirow{2}{*}{ الإفراط في المصروفات } \\
\hline & & 1.72 & 8.60 & 123 & $\gamma$ & \\
\hline \multirow{2}{*}{ غير دالة } & \multirow{2}{*}{1.360} & 4.90 & 60.67 & 93 & نعم & \multirow{2}{*}{ الدرجة الكلية } \\
\hline & & 5.02 & 59.74 & 123 & $y$ & \\
\hline
\end{tabular}

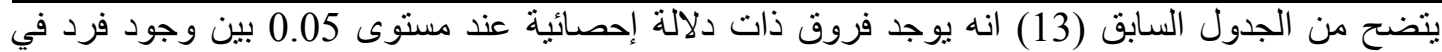

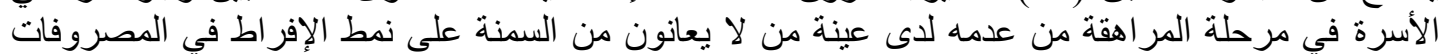

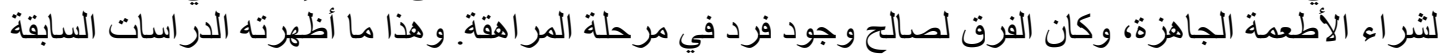
عن السمنة في السعودية وتقارير وزارة الصحة السعودية (2017، 2010) عن انتشار نسبة السمنة في المجتمع 


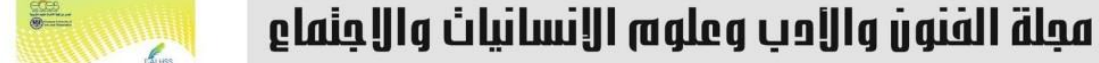 \\ Journal of Arts, Literature, Humanities and Social Sciences www.jalhss.com \\ العدد (68) يونيو 2021

بشكل عام، وهو أمر بديهي حيث أن المراهقون لايهح حرية أكبر في الخروج من المنزل، و أيضاً بتوفر لايهر

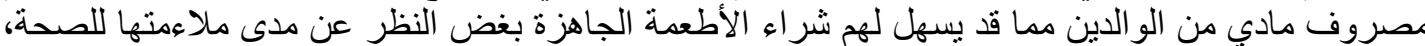

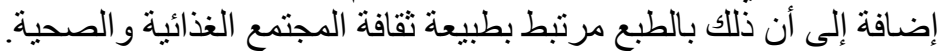

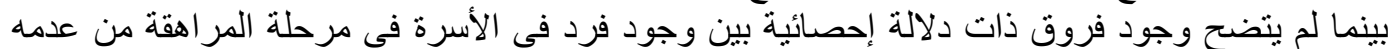

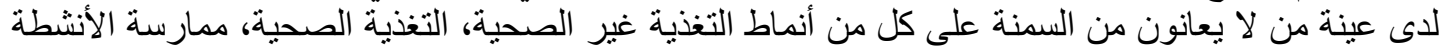
الرياضية و الدرجة الكلية.

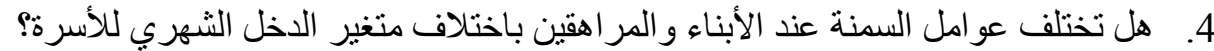

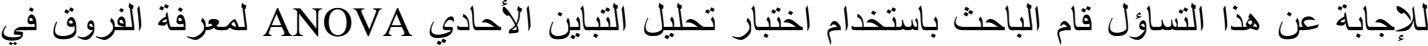
عو امل السمنة عند الأبناء و المر اهقين باختلاف الاخخل الثهري، فكانت النتائج على النحو التالي:

جدول (14) يوضح الفروق في مستويات الدخل الثهري للأسرة على من يعانون من السمنة

\begin{tabular}{|c|c|c|c|c|c|c|}
\hline الالالة & F.test & $\varepsilon$ & b & ن & الاخل الشهري & العوامل - ل الع \\
\hline \multirow{3}{*}{ غير دالة } & \multirow{3}{*}{.995} & 3.32159 & 22.5714 & 14 & أقل من 4000 ربال & \multirow{3}{*}{ الصحية $\quad$ غير } \\
\hline & & 2.68832 & 22.1304 & 46 & من 4001 إلى 9000 & \\
\hline & & 2.31219 & 22.7344 & 128 & من 9001 فأكثر & \\
\hline \multirow{3}{*}{ غير دالة } & \multirow{3}{*}{.124} & 1.40055 & 12.5000 & 14 & أقل من 4000 ريال & \multirow{3}{*}{ لتفنية } \\
\hline & & 2.40651 & 12.8261 & 46 & من 4001 إلى 9000 & \\
\hline & & 2.10362 & 12.7500 & 128 & من 9001 فأكثر & \\
\hline \multirow{3}{*}{ غير دالة } & \multirow{3}{*}{.089} & 1.94992 & 14.5714 & 14 & أقل من 4000 ربال & \multirow{3}{*}{ ممارسة } \\
\hline & & 2.68301 & 14.8478 & 46 & من 4001 إلى 9000 & \\
\hline & & 2.55645 & 14.8750 & 128 & من 9001 فأكثر & \\
\hline \multirow{3}{*}{ غير دالة } & \multirow{3}{*}{2.969} & 2.11224 & 8.0000 & 14 & أقلّ من 4000 ربيال & \multirow{3}{*}{ المصروفات في } \\
\hline & & 1.71566 & 9.1087 & 46 & من 4001 إلى 9000 & \\
\hline & & 1.33758 & 8.9219 & 128 & من 9001 فأكثر & \\
\hline \multirow{3}{*}{ غير دالة } & \multirow{3}{*}{.864} & 3.77455 & 57.6429 & 14 & أقلّ من 4000 ربيال & \multirow{3}{*}{ الارجة الكلية } \\
\hline & & 5.78437 & 58.9130 & 46 & من 4001 إلى 9000 & \\
\hline & & 4.06044 & 59.2813 & 128 & من 9001 فأكثر & \\
\hline
\end{tabular}

يتضح من الجدول السابق (14) انه لا يوجد فروق ذات دلالة إحصائية بين مستويات الدخل على أنماط السمنة

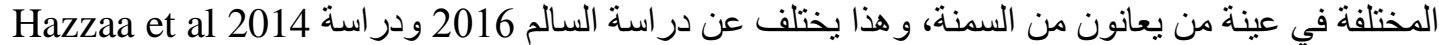
و اللتين بينتا أن ارتفاع المستوى الاقتصادي للأسرة له علاقة ارتباطية بزيادة الوزن و السمنة.

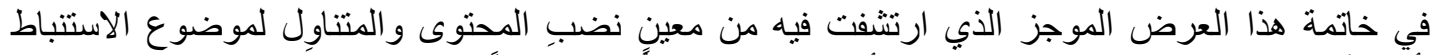
وأخلصُ إلى جملة من النتائج و التوصيّات، فأما النتائج فدونكم أهمها إنمالاً:

النتائج التي وتوصلنا لها:

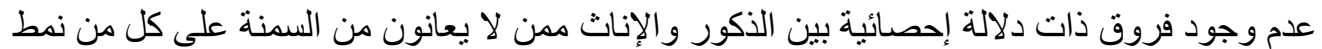

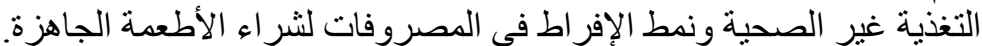

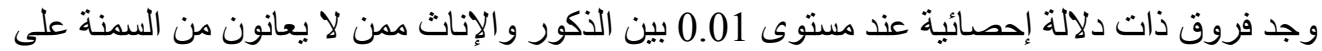
أنماط التغذية الصحية وكان الفرق لصات الصالح الإناث. وجد فروق ذات دلالة إحصائية تراوحت بين مستوى 0.001 بين الذكور والإنات الإناث ممن بعانون من السمنة على نمط ممارسة الأنشطة الرياضية. 


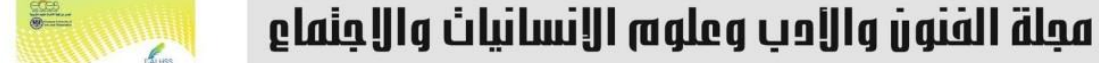 \\ Journal of Arts, Literature, Humanities and Social Sciences www.jalhss.com

وجد فروق ذات دلالة إحصائية عند مستوى 0.05 بين الذكور والإناث ممن لا يعانون من السمنة على

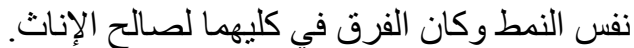

وجد فروق ذات دلالة إحصائية عند مستوى 0.001 و 0.01 بين الذكور والإناث ممن بعانون من الإن الإن السمنة ومنٍ من لا يعانون من السمنة على الدرجة الكلية لأنماط السمنة، وكان الفرق في كليهما لصالح الإناث أيضناً.

وجود فروق ذات دلالة إحصائية عند مستوى 0.05 بين المستوي التعليمي الجامعي والدر اسات العليا على عينة من بيعانون من السمنة. وجود فروق ذات دلالة إحصائية عند مستوى 0.05 بين المستوي التعليمي الثانوي والجامعي للو الدين

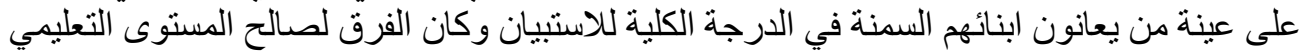

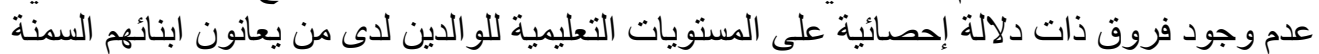
في كل من أنماط التغذية الصحية، ممارسة الأنشطة الرياضية، ونمط الإفر اط في المصروفات لثراء الأطعمة الجاهزة.

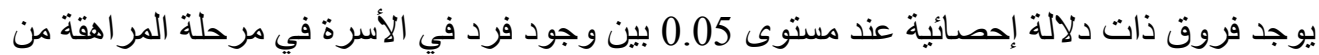

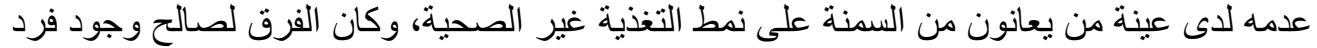
في مرحلة المر اهقة. اتضح وجود فروق ذات دلالة إحصائية عند مستوى 0.05 بين وجود فرد في الأسرة في مرحلة

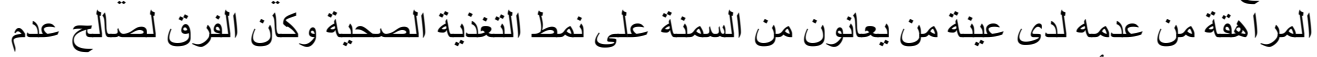
وجود فرد في الأسرة في مرحلة المر اهقة.

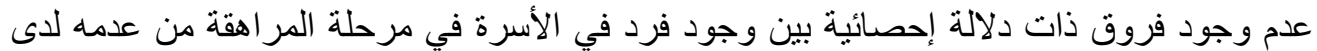

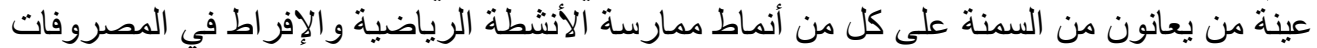
لشر اء الأطعمة الجاهزة.

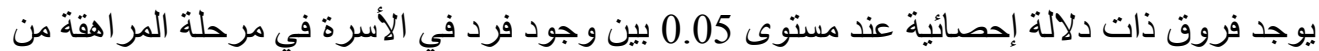

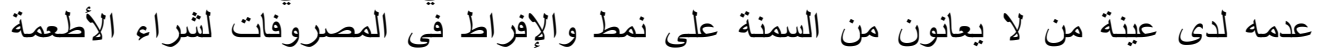

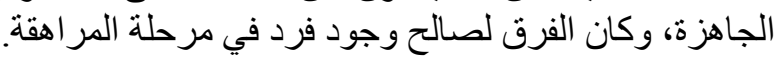

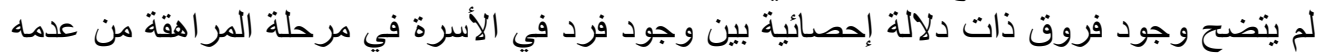

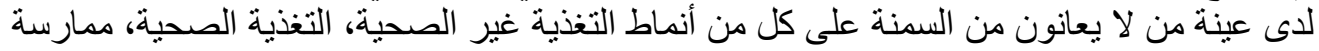

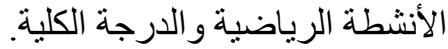
لا يوجد فروق ذات دلالة إحصائية بين مستويات الدخل الأسرة على أنماط السمنة المختلفة في عينة من بعانون من السمنة.

في ضوء النتائج التي توصل لها الباحث، هناللك مجموعة من التوصيات التي يوصى صانعي القرار بوضعها 1. تتظيم حملات توعوية اجتماعية واسعة لتعريف المجتمع بأنماط التغذية الغير صحية والتحذير من خطورتها.

2. الاهتمام بالأنماط الغذائية لدى الاشخاص الذين لا يعانون من السمنة، حيث بظن البعض ان النمط

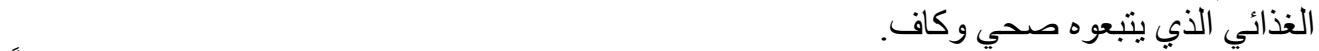
3. توجيه الاسر نحو تقنين الانفاق على الاطعمة الجاهزة والاهتمام بإعداد الاكل الصحي و المغذي وفقاً لطبيعة وسن افر اد الأسرة. 4. الاهتمام بالمر اهقين من حيث التو عية بمجالات الصحة لاسيما المرتبطة بعادات التغذية وأنماطها. 5. اطلاق حملات قومية تستهدف كافة أفر اد المجتمع بهدف تو عيتهم بأهمية الأنماط الغذائية الصحية. 


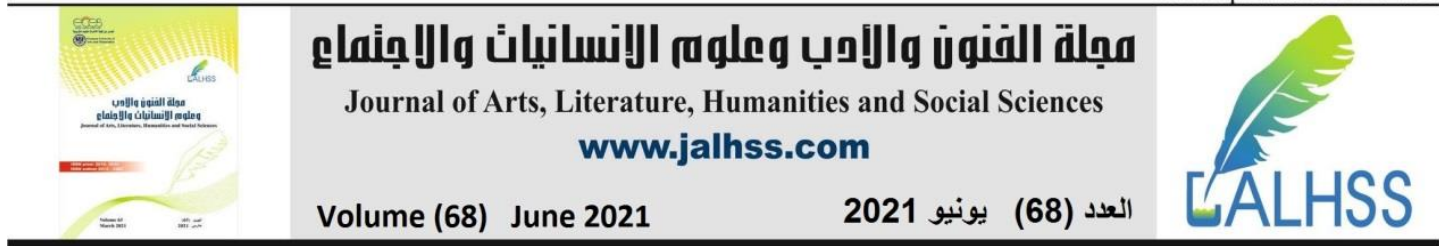

(المصادر

1. الزعبي، احمد (2013). سيكلوجية المر اهقة، زهر ان للنشر ، الطبعة الاولى.

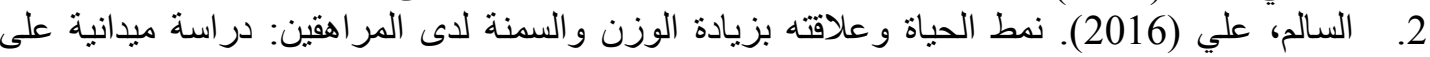
طلاب المرحلة الثانوية بمدينة الرياض. دراسة دكتور اه. قسم الدراسات الاجتماعية، جامعة الملك سعود، دالكة

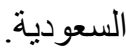

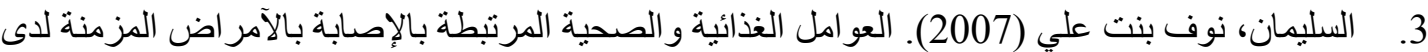

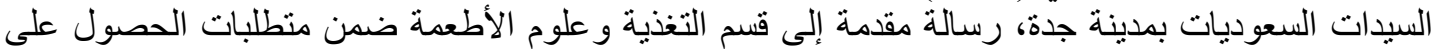
درجة الماجستير في قسم التغذية و علوم الأطعمة تخصص تلفية تلفية طبقية، جامعة الملك عبد العزيز ، جدة، المملكة العربية السعودية. 4. . العطوي، هيا (1439). تعلمت من المر اهقات، ينبع، السعودية. Available: http://www.alukah.net 5. مداوي، جميل (2016). المر اهقة خصائصها ومشكلاتها وحلولها، الناضور ــ المغرب. Available: http://www.alukah.net 6. ملحم، سامي محمد (2014). علم نفس النمو (دورة حياة الإنسان)، المملكة الأردنية الهاثمية، عمان، دار الفكر ناشرون وموزعون، الطبعة الثالثة.

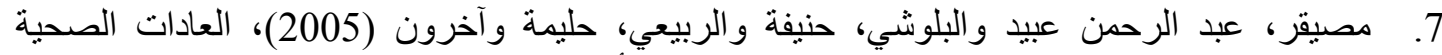
و الغذائية عند النساء في سلطنة عمان: دراسة ميدانية، الطبعة الأولى، مركز البحرين للار اسات و البحوث، دولة البهات

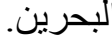
8. باساغانا: مبادئ في علم النفس الاجتماعي، ترجمة. بوعبد الله غلام الله، ديوان المطبوعات

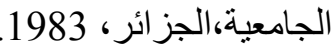
9. حجاج، علي و عطية هنا (1986). نظريات التيات التعليح. دار المعرفة، الكويت.

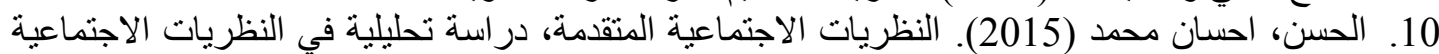
المعاصرة. دار و ائل للنشر، عمان الطبد الطبعة الثالثة. 11. شتا، السيد علي (1999). نظرية الدور و المنظور الظاهري لعلم الاجتماع، مكتبة ومطبعة الإشعاع الفنية، الاسكندرية.

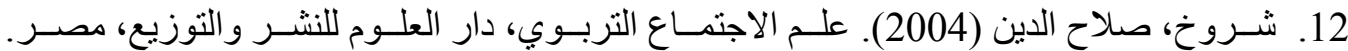

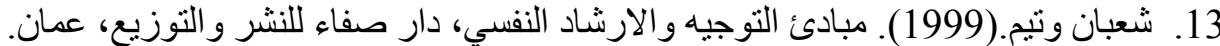

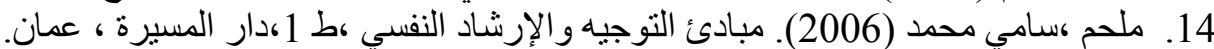

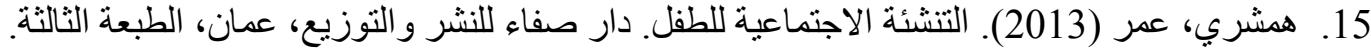

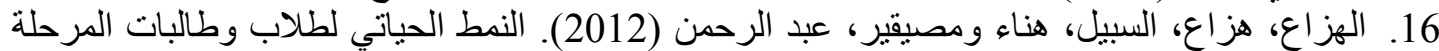

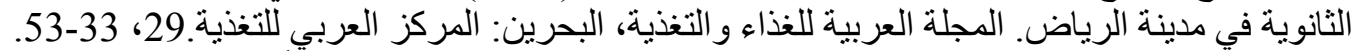

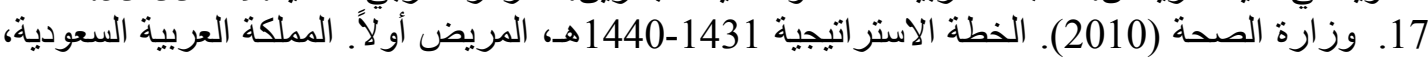

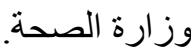
18. وزارة الصحة (2017). مبادرة خفض معدلات السمنة لدى الطلاب والطالبات في المدارس (رشاقة). المملكة العربية السعودية، وزارة الصة الصحة. 19. منظمة الصحة العالمية. (2019). 5 نصائح لنظام غذائي صحي في هذا العام الجديد. جنيف، منظمة

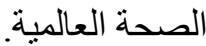

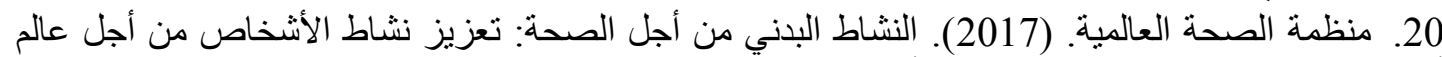

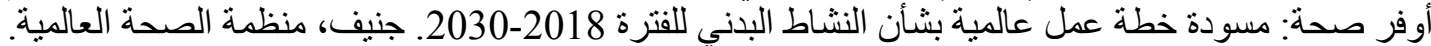
21. منظمة الصحة العالمية (2016). تقرير اللجنة المعنية بالقضاء على سمنة الأطفال. جنيف، منظمة الصحة الصنة 


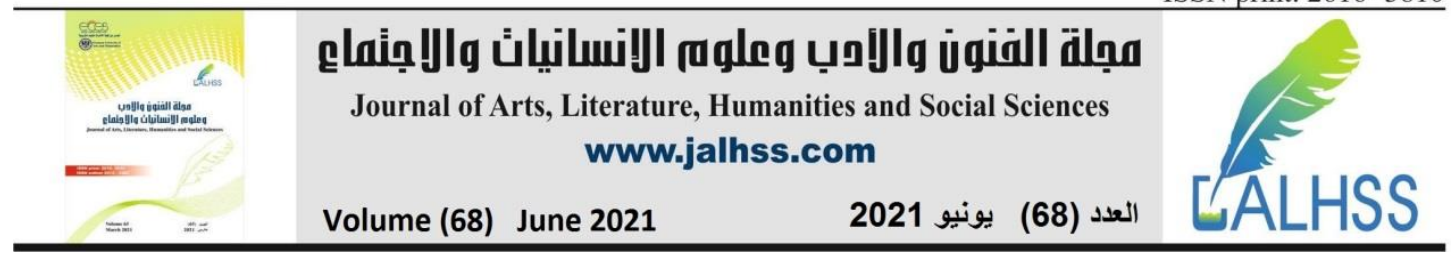

\section{References}

1. Abdelkarim O, Ammar A, Trabelsi K, Cthourou H, Jekauc D, Irandoust K, Taheri M, Bos K, Woll A, Bragazzi N and Hoekelmann A.(2019). Prevalence of Underweigt and Overweight and Its Association with Physical Fitness in Egyptian Schoolchildren. International Journal of Environmental Research and Public Health.17, 75-86.

2. Afolabi, W, Addo, A and Sonibare, M. (2004). Activity pattern, energy intake and obesity among Nigerian urban market women. International Journal of Food Sciences and Nutrition. 55(2), 85-90.

3. Asut O, Abuduxike G, Acar-Vaizoglu S and Cali S. (2019). Relationships Between Screen Time, Internet Addiction and Other Lifestyle Behaviors with Obesity among Secondary School Students in the Turkish Republic of Northern Cyprus. The Turkish Journal of Pediatrics, 61, 568-579.

4. Al-Hazzaa H, Abahussain N, Al-Sobayel H, Qahwaji D, Alsulaiman N and Musaiger A. (2014). Prevalence of Overweight, Obesity, and Abdominal Obesity among Urban Saudi Adolescents: Gender and Regional Variations. J HEALTH POPUL NUTR, 32(4), 634-645.

5. Danford C, Schultz C and Marvicsin D. (2015). Parental Roles in the Development of Obesity in Children: Challenges and Opportunities. Research and Reports in Biology,6, 39-53.

6. Pediatr ResMiller AL, Lee HJ and Lumeng JC. (2015). Obesity-associated biomarkers and executive function in children. Pediatr Res. 77,143-7.

7. McPherson NO, Fullston T, Aitken RJ, Lane M. (2014) Paternal obesity, interventions, and mechanistic pathways to impaired health in offspring. Ann Nutr Metab. 64, 231-8.

8. El Mouzan MI, Foster PJ, Al Omer AA, Qurachi MM, and Kecojevic T. (2010). Prevalence of Overweight and Obesity in Saudi Children and Adolescents. International Journal of Obesity, 30, 203-208.

9. El Kabbaui M, Chda A, Bousfiha A, Aarab L, Bencheikh R, Tazi A. (2018) Prevalence of and Risk Factors for Overweight and Obesity among Adolescents in Morocco. East Mediterr Health J. 24, 512-521.

10. Gray L, Alava M, Kelly M and Campbell M. (2018). Family Lifestyle Dynamics and Childhood Obesity: Evidence from the Millennium Cohort Study. BMC Public Health, 18, 500-515.

11. Eker H, Tasdemir M, Mercan S, Mucaz M, Bektemur G, Sahinoz S and Ozkaya E. (2018). Obesity in Adolescents and the Risk Factors. Turk J Phys Med Rehab, 64 (1), 37-45.

12. Muthuri SK, Onywera VO, Tremblay MS, Broyles ST, Chaput J-P and Fogelholm et al. (2016). Relationships between Parental Education and Overweight with Childhood Overweight and Physical Activity in 9-11 Years Old Children: Results from 12 Country Study. PLoS ONE, 11(8), 1-14.

13. Poček S, Trivić T, Roklicer R, Ostojić S and Drid P. (2018). Long-Term Outcomes of Sports on Health Status: A Mini Review. EQOL Journal,10(1), 5-15. 


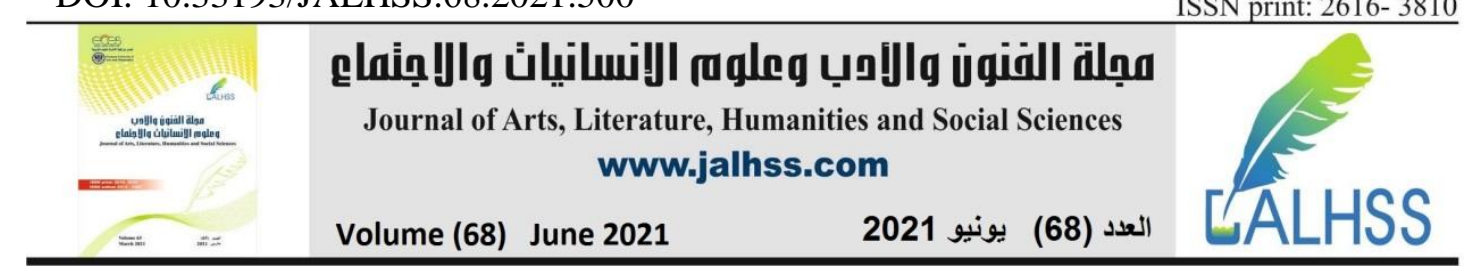

14. Scaglioni S, Cosmi V, Ciappolino V, Parazzini F, Brambilla P and Agostoni C. (2018). Factors Influencing Children's Eating Behaviours. Nutrients, 10, 706722.

15. Sahoo K, Sahoo B, Choudhury AK, Sofi NY, Kumar R and Bhadoria AS.)2015). Childhood Obesity: Causes and Consequences. J Family Med Prim Care, 4(2), 187-192.

16. Stranford Medicine@2020 Stranford Medicine.

17. World Health Organization. (2016). Report of the Commission on Ending Childhood Obesity. Geneva, WHO.

18. World Health Organization. (2010). Framework for the implementation of the Global Strategy on Diet, Physical Activity and Health in the Eastern Mediterranean Region. Geneva, WHO.

19. Wang Y. (2017)."Chapter 9. Potential mechanisms in childhood obesity: causes and prevention", In "Energy balance and obesity, IARC Working Group Reports, Volume 10, 2017", Edited by Isabelle Romieu, Laure Dossus, and Walter C. Willett. Geneva: WHO.

20. Williams SE, Greene JL (2018) Childhood Overweight and Obesity: Affecting Factors, Education and Intervention. Journal of Childhood Obesity, 3 (2: 9), 1-7. 